Prepared in cooperation with the city of Rapid City and the West Dakota Water Development District

\title{
Analysis of Ground-Water Flow in the Madison Aquifer using Fluorescent Dyes Injected in Spring Creek and Rapid Creek near Rapid City, South Dakota, 2003-04
}

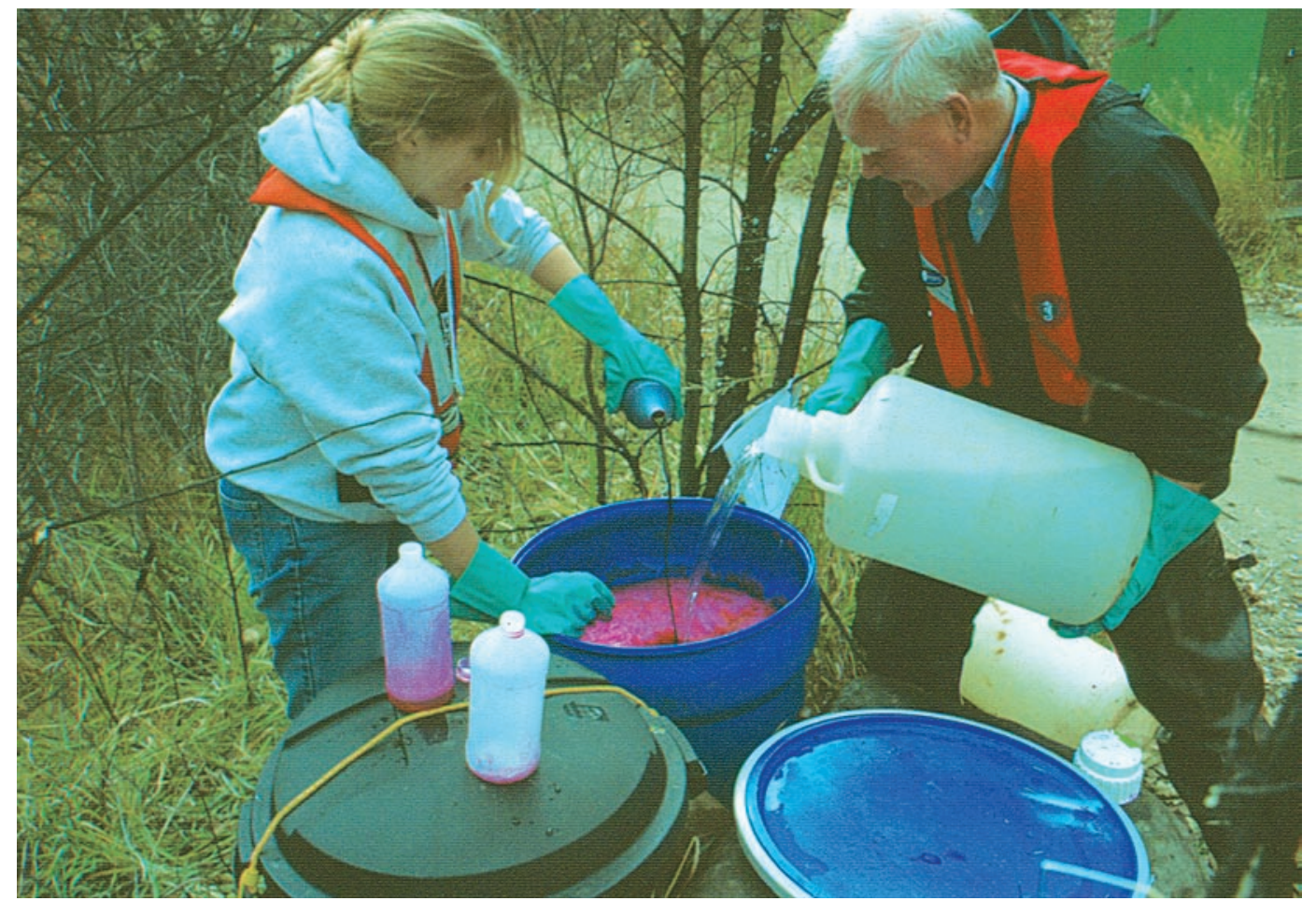

Scientific Investigations Report 2007-5137 
Cover: Photograph of mixing the Rhodamine WT dye for injection in Rapid Creek at miscellaneous gaging station 06412200 (photograph by Andrew J. Long, U.S. Geological Survey). 


\section{Analysis of Ground-Water Flow in the Madison Aquifer using Fluorescent Dyes Injected in Spring Creek and Rapid Creek near Rapid City, South Dakota, 2003-04}

By Larry D. Putnam and Andrew J. Long

Prepared in cooperation with the city of Rapid City and the West Dakota Water Development District

Scientific Investigations Report 2007-5137 


\section{U.S. Department of the Interior DIRK KEMPTHORNE, Secretary}

\section{U.S. Geological Survey \\ Mark D. Myers, Director}

\section{U.S. Geological Survey, Reston, Virginia: 2007}

For product and ordering information:

World Wide Web: http://www.usgs.gov/pubprod

Telephone: 1-888-ASK-USGS

For more information on the USGS--the Federal source for science about the Earth, its natural and living resources, natural hazards, and the environment:

World Wide Web: http://www.usgs.gov

Telephone: 1-888-ASK-USGS

Any use of trade, product, or firm names is for descriptive purposes only and does not imply endorsement by the U.S. Government.

Although this report is in the public domain, permission must be secured from the individual copyright owners to reproduce any copyrighted materials contained within this report.

Suggested citation:

Putnam, L.D., Long, A.J., 2007, Analysis of ground-water flow in the Madison aquifer using fluorescent dyes injected in Spring Creek and Rapid Creek near Rapid City, South Dakota, 2003-04: U.S. Geological Survey Scientific Investigations Report 2007-5137, 27 p. 


\section{Contents}






\section{Figures}

1. Location of study area, dye injection sites, and sampling sites ........................................

2. Stratigraphic section for the study area ......................................................................... 4

3. Simplified hydrogeologic setting in the Black Hills area ...................................................5

4. Joy's Loss swallow hole (site S4), located on south side of Spring Creek, South Dakota

5. Daily mean streamflow for station 06407500 (Spring Creek near Keystone, South Dakota) located upstream from the streamflow loss zone ...............................................

6. Location of sampling sites, Rapid Creek, South Dakota (see figure 1, insert A) ..............8

7. Location of sampling sites, Rapid Creek, South Dakota (see figure 1, insert B) .............10

8. Boxplots of fluorescein concentrations in background and blank samples ...................12

9. Comparison of initial fluorescein concentrations with concentrations in the same samples that were stored for about 1 year .......................................................................13

10. Boxplots of Rhodamine WT concentrations in background and blank samples.............13

11. Fluorescein dye breakthrough curves for well $\mathrm{CO}$ following three dye injections in Spring Creek, South Dakota, in 2003

12. Fluorescein dye breakthrough curves for wells NON, NAY, and CRO following three dye injections in Spring Creek, South Dakota, in 2003 ......................................................18

13. Fluorescein dye breakthrough curve for well CO following dye injection in Spring Creek, South Dakota, in 2004

14. Fluorescein dye breakthrough curves for wells NON, NAY, CRO, HH, and CSN4 following dye injection in Spring Creek, South Dakota, in 2004. 19

15. Rhodamine WT dye breakthrough curves for well DRU and spring TI-SP following dye injection in Rapid Creek, South Dakota, in 2004.

16. Rhodamine WT dye concentrations for Jackson Springs gallery samples following injection in Rapid Creek, South Dakota, in 2004

17. Time-series data of Rhodamine WT concentrations in samples from Rapid Creek sites and from Jackson Springs Gallery, Rapid Creek, South Dakota .....

18. Comparison of fluorescein dye breakthrough curves for well NON for 2003 and 2004 injections in Spring Creek, South Dakota....

\section{Tables}

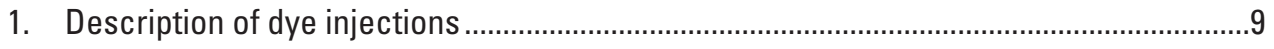

2. Well, spring, and stream sites where samples were collected for dye analysis ...........11

3. Summary of fluorometric analysis of water samples for fluorescein dye following injections in 2003 at sites S1 (April 29), S2 (May 22), and S3 (May 29), Spring Creek, South Dakota

4. Summary of fluorometric analysis of water samples for fluorescein dye following injection at site S4 on March 28, 2004, Spring Creek, South Dakota

5. Summary of fluorometric analysis of water samples for Rhodamine WT dye following injection at site R1, Rapid Creek, South Dakota.

6. Estimated ground-water velocities based on dye tracing for Spring Creek, South Dakota 


\section{Conversion Factors}

\begin{tabular}{lcl}
\hline Multiply & By & To obtain \\
\hline inch (in.) & Length & \\
foot (ft) & 2.54 & centimeter $(\mathrm{cm})$ \\
mile (mi) & 0.3048 & meter $(\mathrm{m})$ \\
\hline & 1.609 & kilometer $(\mathrm{km})$ \\
\hline square mile $\left(\mathrm{mi}^{2}\right)$ & Area & \\
\hline & 2.590 & square $\mathrm{kilometer}\left(\mathrm{km}^{2}\right)$ \\
\hline gallon $(\mathrm{gal})$ & Volume & \\
cubic foot $\left(\mathrm{ft}^{3}\right)$ & 3,785 & milliliter $(\mathrm{mL})$ \\
& 0.02832 & cubic meter $\left(\mathrm{m}^{3}\right)$ \\
\hline cubic foot per second $(\mathrm{ft} / \mathrm{s})$ & Flow rate & \\
gallon per minute $(\mathrm{gal} / \mathrm{min})$ & 0.02832 & cubic meter per second $\left(\mathrm{m}^{3} / \mathrm{s}\right)$ \\
gallon per day (gal/d) & 0.06309 & liter per second $(\mathrm{L} / \mathrm{s})$ \\
million gallons per day $(\mathrm{Mgal} / \mathrm{d})$ & 0.003785 & cubic meter per day $\left(\mathrm{m}^{3} / \mathrm{d}\right)$ \\
\hline & 0.04381 & cubic meter per second $\left(\mathrm{m}^{3} / \mathrm{s}\right)$ \\
\hline pound, avoirdupois $(\mathrm{lb})$ & Mass & \\
\hline
\end{tabular}

Vertical coordinate information is referenced to the North American Vertical Datum of 1929 (NAVD 29).

Horizontal coordinate information is referenced to the North American Datum of 1927 (NAD 27).

Altitude, as used in this report, refers to distance above the vertical datum.

*Transmissivity: The standard unit for transmissivity is cubic foot per day per square foot times foot of aquifer thickness [(ft3 $\left./ \mathrm{d}) / \mathrm{ft}^{2}\right] \mathrm{ft}$. In this report, the mathematically reduced form, foot squared per day $\left(\mathrm{ft}^{2} / \mathrm{d}\right)$, is used for convenience.

Concentrations of chemical constituents in water are given in micrograms per liter ( $\mu \mathrm{g} / \mathrm{L})$.

Water year (WY) is the 12-month period, 0ctober 1 through September 30, and is designated by the calendar year in which it ends. Thus, the water year ending September 30, 2003, is called "water year 2003." 
This page intentionally left blank 


\title{
Analysis of Ground-Water Flow in the Madison Aquifer using Fluorescent Dyes Injected in Spring Creek and Rapid Creek near Rapid City, South Dakota, 2003-04
}

\author{
By Larry D. Putnam and Andrew J. Long
}

\section{Abstract}

The Madison aquifer, which contains fractures and solution openings in the Madison Limestone, is used extensively for water supplies for the city of Rapid City and other suburban communities in the Rapid City, S. Dak., area. The 48 square-mile study area includes the west-central and southwest parts of Rapid City and the outcrops of the Madison Limestone extending from south of Spring Creek to north of Rapid Creek. Recharge to the Madison Limestone occurs when streams lose flow as they cross the outcrop. The maximum net loss rate for Spring and Rapid Creek loss zones are 21 and 10 cubic feet per second $\left(\mathrm{ft}^{3} / \mathrm{s}\right)$, respectively. During 2003 and 2004, fluorescent dyes were injected in the Spring and Rapid Creek loss zones to estimate approximate locations of preferential flow paths in the Madison aquifer and to measure the response and transit times at wells and springs. Four injections of about 2 kilograms of fluorescein dye were made in the Spring Creek loss zone during 2003 (sites S1, S2, and S3) and 2004 (site S4). Injection at site S1 was made in streamflow just upstream from the loss zone over a 12-hour period when streamflow was about equal to the maximum loss rate. Injections at sites S2, S3, and S4 were made in specific swallow holes located in the Spring Creek loss zone. Injection at site R1 in 2004 of 3.5 kilograms of Rhodamine WT dye was made in streamflow just upstream from the Rapid Creek loss zone over about a 28 -hour period. Selected combinations of 27 wells, 6 springs, and 3 stream sites were monitored with discrete samples following the injections.

For injections at sites S1-S3, when Spring Creek streamflow was greater than or equal to $20 \mathrm{ft}^{3} / \mathrm{s}$, fluorescein was detected in samples from five wells that were located as much as about 2 miles from the loss zone. Time to first arrival (injection at site $\mathrm{S} 1$ ) ranged from less than 1 to less than 10 days. The maximum fluorescein concentration (injection at site S1) of 120 micrograms per liter ( $\mu \mathrm{g} / \mathrm{L})$ at well CO, which is located adjacent to the loss zone, was similar to the concentration in the stream. Fluorescein arrived at well NON (injection at site S1), which is located about 2 miles northeast of the loss zone, within about 1.6 days, and the maximum concentration was $44 \mu \mathrm{g} / \mathrm{L}$. For injection at site S4, when streamflow was about $12 \mathrm{ft}^{3} / \mathrm{s}$, fluorescein was detected in samples from six wells and time to first arrival ranged from 0.2 to 16 days. Following injection at site S4 in 2004, the length of time that dye remained in the capture zone of well NON, which is located approximately 2 miles from the loss zone, was almost an order of magnitude greater than in 2003. For injection at site R1, Rhodamine WT was detected at well DRU and spring TI-SP with time to first arrival of about 0.5 and 1.1 days and maximum concentrations of 6.2 and $0.91 \mu \mathrm{g} / \mathrm{L}$, respectively. Well DRU and spring TI-SP are located near the center of the Rapid Creek loss zone where the creek has a large meander. Measurable concentrations were observed for spring TI-SP as many as 109 days after the dye injection. The direction of a conduit flow path in the Spring Creek area was to the northeast with ground-water velocities that ranged from 770 to 6,500 feet per day. In the Rapid Creek loss zone, a conduit flow path east of the loss zone was not evident from the dye injection.

\section{Introduction}

The Madison aquifer is used extensively for water supplies for the city of Rapid City, S. Dak., and other suburban communities in the surrounding area. A better understanding of ground-water flow in this complex hydrologic setting is needed to manage and protect this important water resource. The Madison Limestone, which contains the Madison aquifer, has extensive fractures and solution-enhanced openings that result in large secondary porosities and permeabilities. An important component of recharge to the Madison aquifer is streamflow loss that occurs as streams cross the Madison Limestone outcrop. Streamflow recharge to the Madison aquifer is associated with conduit formation in the limestone and rapid ground-water velocities.

A cooperative study between the city of Rapid City, West Dakota Water Development District, and the U.S. Geological Survey (USGS) was initiated in 2003 to conduct tracer testing of ground-water flow in the Madison aquifer using environmentally safe fluorescent dyes in the Spring Creek and Rapid Creek areas during 2003-04. The results of 
the dye tracing were used to help determine approximate locations of preferential flow paths in the Madison aquifer originating from streamflow loss zones on Spring Creek and Rapid Creek and to measure concentrations and transit times of a conservative tracer at wells and springs. Results of this study may be helpful for water managers when considering contamination potential or the construction of new wells, and provide information to improve the general understanding of the ground-water flow in the Madison aquifer. Because of the numerous water supply wells in the study area and uncertainty in the hydraulic connections of many of these wells to rapid flow paths, dye injections were designed to minimize the possibility of concentrations large enough to discolor water in wells.

\section{Purpose and Scope}

The purpose of this report is to describe the results of tracer testing of ground-water flow in the Madison aquifer using fluorescent dyes in Spring Creek and Rapid Creek near Rapid City, S. Dak. Dye concentrations and transit times to downgradient sites are presented for three fluorescein injections in 2003 and one fluorescein injection in 2004 in the Spring Creek loss zone and for one Rhodamine WT injection in the Rapid Creek loss zone in 2004. Ground-water flow paths and velocities in the Rapid City area are described on the basis of dye tracing results.

\section{Description of the Study Area}

The 48-square-mile $\left(\mathrm{mi}^{2}\right)$ study area is located on the east-central flank of the Black Hills (fig. 1) and includes the areas where Spring and Rapid Creeks cross the Madison Limestone outcrop. The study area includes the west-central and southwest parts of Rapid City and the adjacent areas south and west of the city. Substantial suburban development is occurring in the area, and numerous public and domestic supply wells have been constructed in the Madison aquifer. Land-surface altitudes range from about 4,200 feet (ft) on the western side of the study area to about 3,200 ft on the eastern side of the study area. The Madison Limestone outcrop is characterized by high-relief forested areas cut by deep canyons with entrenched meanders and steep cliffs formed in the limestone. The eastern part of the study area is characterized by less relief and fewer forested areas. Average precipitation during 1961 to 1990 ranged from about 19 inches (in.) on the western side of the study area to $18 \mathrm{in}$. on the eastern side of the study area (Driscoll and others, 2000).

\section{Previous Investigations}

Previous dye-tracer studies for the Madison aquifer in the Rapid City area include Rahn (1971), Rahn and Gries (1973), and Greene (1999) that examined streamflow loss to the Madison aquifer for Boxelder Creek, which is north of the study area. Anderson and others (1999) described groundwater and surface-water interactions along Rapid Creek near Rapid City. An overview of flow paths in the Madison aquifer on the basis of stable isotopes, tritium, and previous dye tests in the Black Hills area is provided in Naus and others (2001). Long and Putnam (2004) analyzed stable-isotope, time-series data to estimate transit times and mixing in the Madison aquifer in the Spring Creek area. Studies of cave development in the Madison Limestone in the Black Hills area include Howard (1964) and Ford (1989).

\section{Acknowledgments}

The authors thank the city of Rapid City for providing extensive assistance with the collection of water samples. The authors also thank the West Dakota Water Development District for assistance with study coordination. Also, several suburban public water associations and their operators were helpful in providing access and assistance in collecting samples from other supply wells. Numerous private well owners also provided access to their wells for the collection of samples. Ericka Oberembt assisted with analysis of samples and compilation of data. Scott Miller provided extensive assistance with site investigations. Andrea Putnam assisted with monitoring dye injections. The South Dakota Game, Fish and Parks (SDGFP) allowed access to springs located on the Cleghorn Springs Fish Hatchery grounds.

\section{Hydrogeologic Setting}

The hydrogeologic setting and the Madison aquifer for Rapid City and the surrounding area are described in detail in Long and Putnam (2002). The following summary of the hydrogeologic setting emphasizes the areas near Spring and Rapid Creeks that are relevant to dye testing.

\section{Hydrogeology}

Uplift at the end of the Cretaceous period and subsequent erosion created the dome-like structure and geomorphology of the Black Hills. Metamorphic and igneous rocks of Precambrian age are exposed in the central core of the Black Hills, whereas younger stratigraphic layers are exposed on its flanks. From an aerial perspective, outcrops of Paleozoic units form concentric rings surrounding the Precambrian core and dip radially outward. One of these stratigraphic layers is the Mississippian-age Madison Limestone, which is composed of karst limestone and dolostone. A stratigraphic section for the Rapid City area (fig. 2) and a schematic diagram of the hydrogeologic setting in the Black Hills area (fig. 3) describe the general characteristics of the rock units and their relation to the Madison Limestone. 


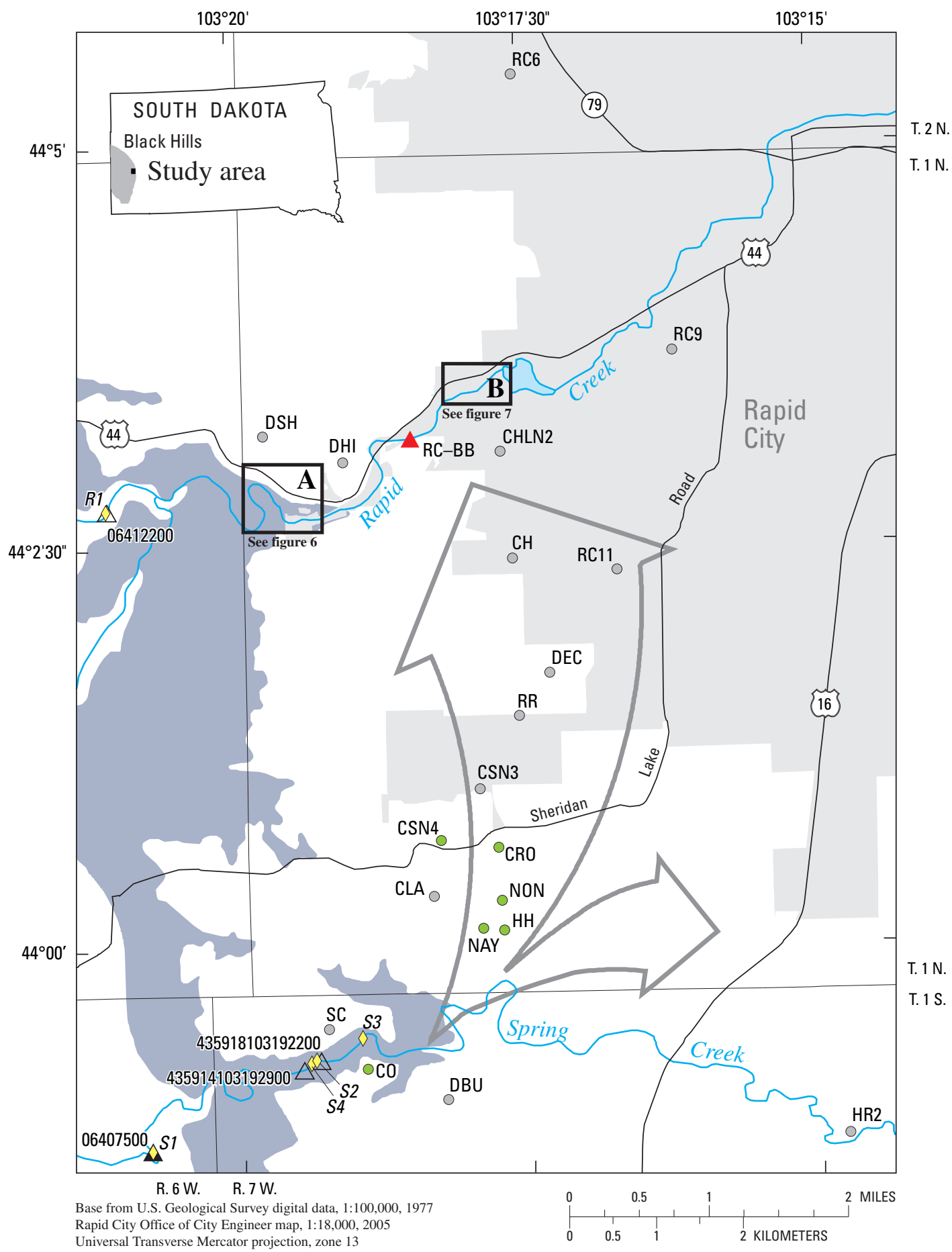

EXPLANATION

Madison Limestone outcrop (Strobel and others, 1999)

$S{ }^{\diamond} \quad$ Dye injection site-Label is site

Continuous-record streamflow-gaging 06407500 station and station number

$\mathrm{C}^{\circ}$ Ground-water sampling site where fluorescein dye was detected-Label is site identification, table 2

$\triangle$ Miscellaneous-record streamflow-gaging 06412200 station and station number

A Stream sampling site RC-BB for Rapid RC-BB Creek-Label is site identification, table 2

$S^{\bigcirc}$ Ground-water sampling site where dye was not detected-Label is site identification, table 2

Generalized flow path from Spring Creek area (Long and Putnam, 2002)

Figure 1. Location of study area, dye injection sites, and sampling sites. 







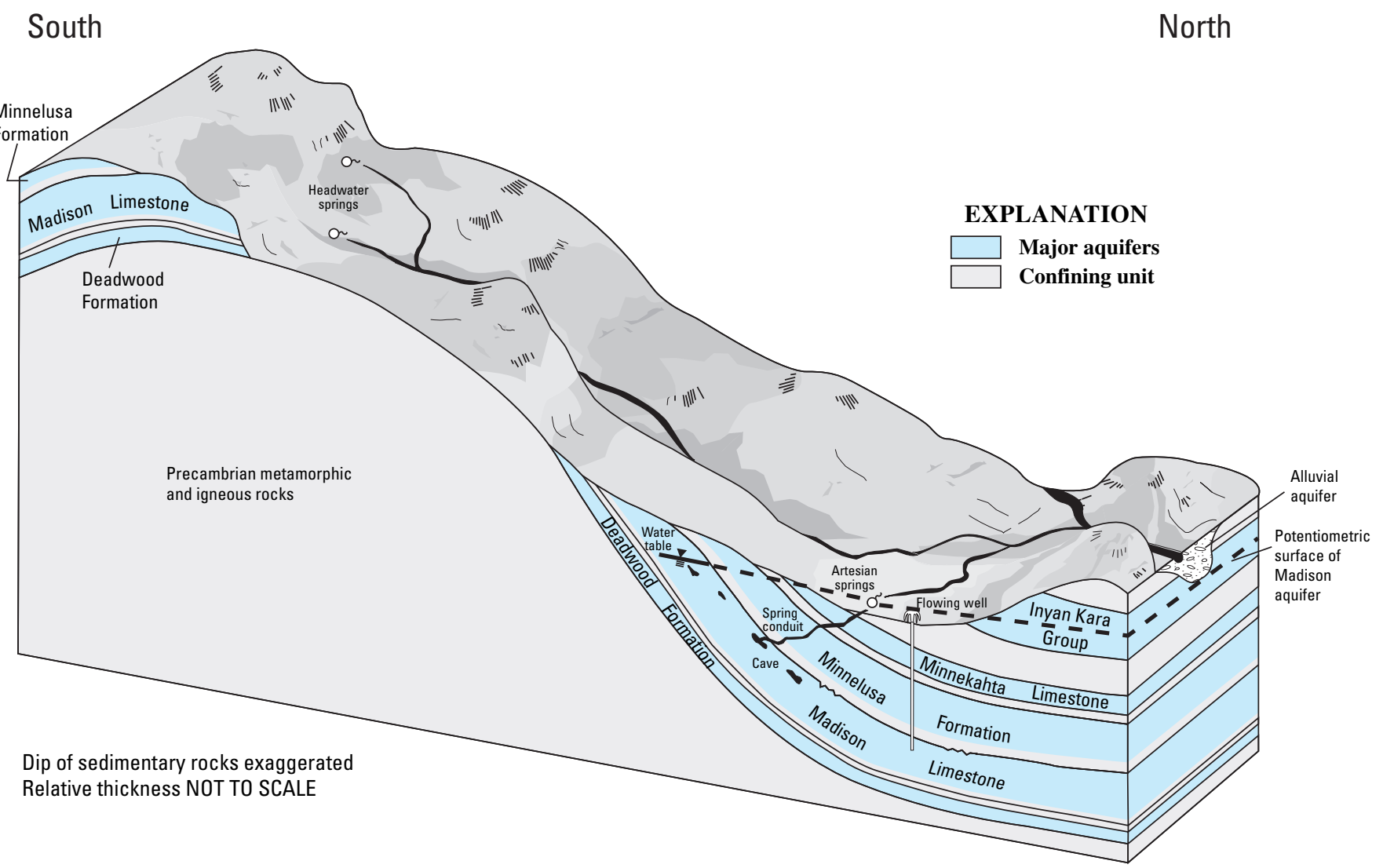

Figure 3. Simplified hydrogeologic setting in the Black Hills area.

The upper surface of the Madison Limestone is a weathered karst surface, unconformable with the overlying Pennsylvanian- and Permian-age Minnelusa Formation (Cattermole, 1969). The Madison aquifer is considered karstic because of the extensive solution enlargement of fractures resulting in major conduits that allow high-velocity groundwater flow. A localized anisotropic permeability (principal direction of transmissivity) has been developed by ground water flowing through fractures, dissolving the rock, and producing dissolution-enhanced conduits along the direction of ground-water flow (Greene and Rahn, 1995). Secondary permeability in the lower part of the Madison Limestone generally is much smaller than in the upper part (Greene, 1993; Miller, 2005); however, the lower part can have high permeability near outcrop areas, especially along stream channels. The Devonian- and Mississippian-age Englewood Formation, which underlies the Madison Limestone and is less than $60 \mathrm{ft}$ thick, has similar properties to those of the lower Madison Limestone. The Englewood Formation is composed of argillaceous, dolomitic limestone and probably could be considered a member of the Madison Limestone because of its lithology (Gries and Martin, 1985). Strobel and others (1999) mapped the Madison Limestone and Englewood Formation as a combined unit. For simplicity, the combined unit is referred to in this report as the Madison Limestone outcrop (fig. 1).

The Madison Limestone was divided into four cliffforming geomorphic units by detailed geologic mapping along Spring Creek, Rapid Creek, and Boxelder Creek canyons (located just north of the study area) by Miller (2005). The thickness of the units described by Miller (2005) from bottom to top are: 130 to $165 \mathrm{ft}$ (unit 1); 81 to $120 \mathrm{ft}$ (unit 2); 140 to $150 \mathrm{ft}$ (unit 3); 0 to $85 \mathrm{ft}$ (unit 4). Late-Mississippian erosion removed the upper part of unit 4 in the Boxelder and Spring Creek areas and all of unit 4 and part of unit 3 in the Rapid Creek area. Unit 1 is highly resistant to erosion with thickly bedded sections and forms nearly vertical cliffs. Unit 2 is similar; however, the bedding is thinner and cliff faces tend to be more irregular. Unit 3 is characterized by massive collapse brecciation with large angular blocks and poorly preserved bedding. Caves are numerous and commonly are filled with cemented solution breccias and cave fill. Unit 4, where present, is characterized by collapse brecciation with angular blocks. Upper cliff surfaces are rounded off because of low resistance to erosion and dissolution. Karst features are found throughout the Madison Limestone; however, they tend to be more common along the contacts between these geomorphic units (Miller, 2005). 


\section{Streamflow Loss Zones}

The streamflow loss zones described in this study include the stream reaches of Spring and Rapid Creeks that cross the Madison Limestone or alluvium overlying the Madison Limestone. Streamflow loss occurs to identifiable swallow holes or to other openings in the Madison Limestone overlain by the alluvial deposits.

\section{Spring Creek}

The Spring Creek loss zone for the Madison Limestone includes about 2.3 river miles that cross the Madison Limestone outcrop (fig. 1). Streamflow losses or gains may occur within sections of the reach; however, a net loss always occurs over the length of the outcrop. The maximum net loss rate for the Madison aquifer is referred to as the loss threshold rate. The estimated loss threshold rate for Spring Creek is 21 cubic feet per second $\left(\mathrm{ft}^{3} / \mathrm{s}\right)$ (Hortness and Driscoll, 1998).

Five swallow holes have been visually identified along the Spring Creek loss zone. Two swallow holes observed in the upper reaches of the loss zone are described in Miller (2005).
The first of these swallow holes occurs at the contact between the Madison Limestone and the Englewood Formation, and the second is at the contact between units 1 and 2 . The other three swallow holes were named by Miller (2005) and correspond to dye injection sites S2, S3, and S4 (fig. 1), which are described in the "Dye Injections" section. The names and corresponding dye injection site labels (fig.1) in downstream order are: Joy's Loss (site S4), Deep Throat (site S2), and Lower Bend (site S3). These swallow holes are located at the contact between Madison Limestone units 2 and 3 (Miller, 2005).

Joy's Loss (site S4) is a Madison Limestone cave located on the south side of the vertical canyon wall at stream level (fig. 4). The ceiling of this cave ranges from about 3 to $7 \mathrm{ft}$ above the cave floor. The cave slopes downward and away from the stream channel for about 50 to $100 \mathrm{ft}$, narrowing to small openings along the perimeter. At higher flows during spring, the cave is mostly flooded; at lower flows during summer, all water in the stream sometimes flows directly into the cave or into sinks underlying the alluvium, leaving nothing to flow in the main channel, which is at a higher altitude than the cave floor. Deep Throat (site S2) is just downstream from Joy's Loss on the north side of the canyon wall and is similar

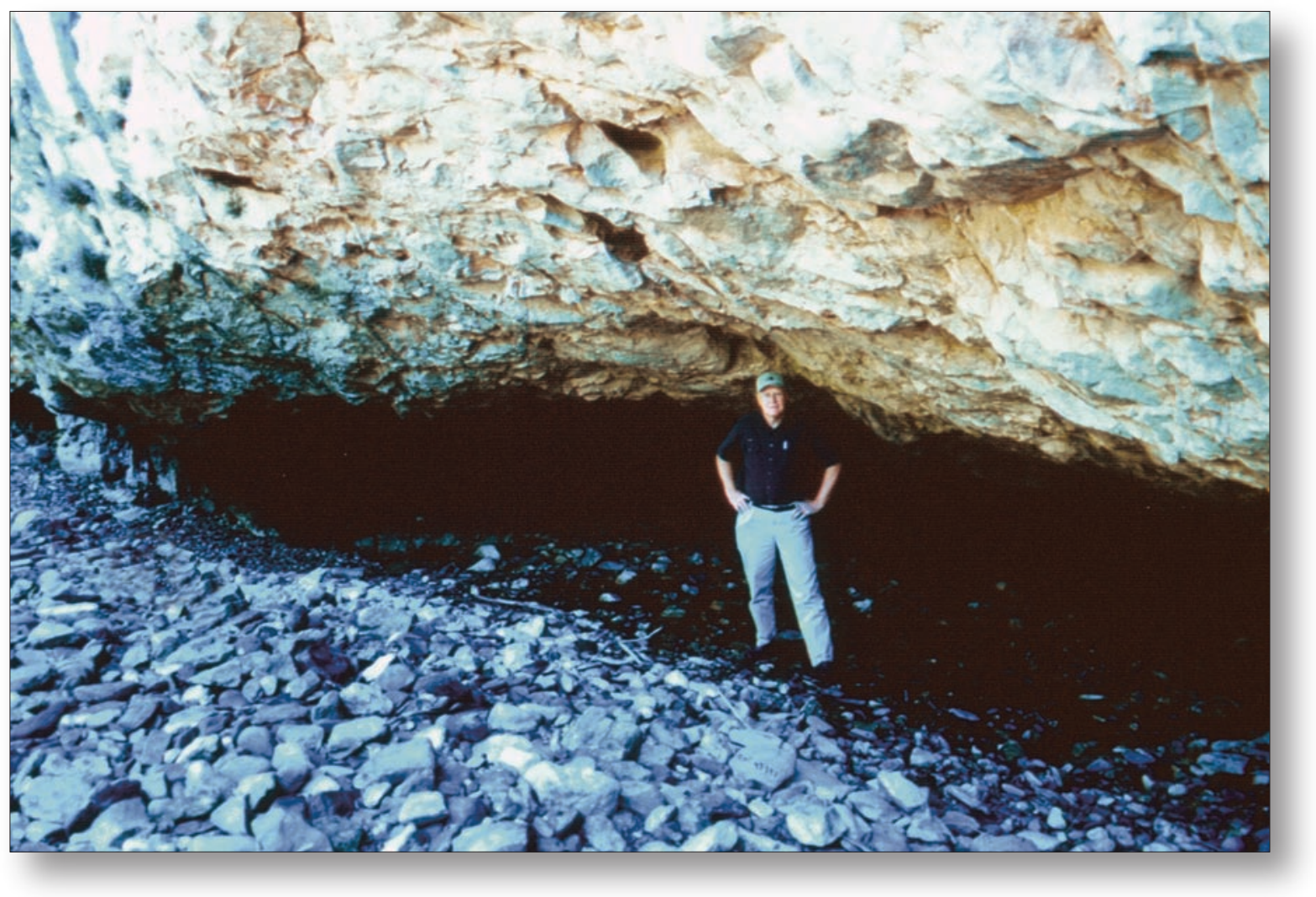

Figure 4. Joy's Loss swallow hole (site S4), located on south side of Spring Creek, South Dakota. 
to Joy's Loss, except the cave entrance at site $\mathrm{S} 2$ is smaller. At higher flows during spring, a steady stream branches off the main channel and enters a downward-sloping throat that is large enough for a person to crawl through for a short distance. While inside this cave and when water was not observed entering from the stream, flowing water can be heard below the cave floor. At lower flows during summer, some or all of the flow (if any) appears to bypass the cave.

On May 28, 2003, streamflow was measured (U.S. Geological Survey, 2004) at station 435914103192900 just upstream from the swallow holes of sites S2 and S4 and at station 435918103192200 downstream from these swallow holes (fig. 1). Streamflow for several days prior to this paired measurement was relatively steady, declining from about 30 to $25 \mathrm{ft}^{3} / \mathrm{s}$ at station 06407500 . The streamflow loss for the reach calculated from the measurements was $14.3 \mathrm{ft}^{3} / \mathrm{s}$. The stream reach that contains sites S2 and S4 accounts for a substantial part of the total streamflow loss to the Madison aquifer.

Lower Bend swallow hole (site S3) is a small depression (2-3 square feet) located at the edge of the stream channel.
The vertical canyon wall composed of Madison Limestone rises from the edge of this depression. At higher flows during spring, the depression is inundated; at lower flow during summer, flow may branch off the main channel and sink into the depression rapidly. Often, streamflow disappears into the swallow holes upstream from site S3, and no recharge occurs at this swallow hole.

The median streamflow for Spring Creek for water years (WY) 1987-2004 for station 06407500 (fig. 1), which is located just upstream from the loss zone, was $7.5 \mathrm{ft}^{3} / \mathrm{s}$ (U.S. Geological Survey, 2005). The median annual streamflow was $4.0 \mathrm{ft}^{3} / \mathrm{s}$ for WY 2003 (U.S. Geological Survey, 2004) and $2.1 \mathrm{ft}^{3} / \mathrm{s}$ for WY 2004 (U.S. Geological Survey, 2005). Daily mean streamflow for station 06407500 for WY 2003 and 2004 is shown in figure 5. During spring 2003, streamflow exceeded or was near the loss threshold of $21 \mathrm{ft}^{3} / \mathrm{s}$ (Hortness and Driscoll, 1998) for most of April, May, and June. In 2004, streamflow during the spring was very low, and flow reached Joy's Loss only for a brief period at the end of March.

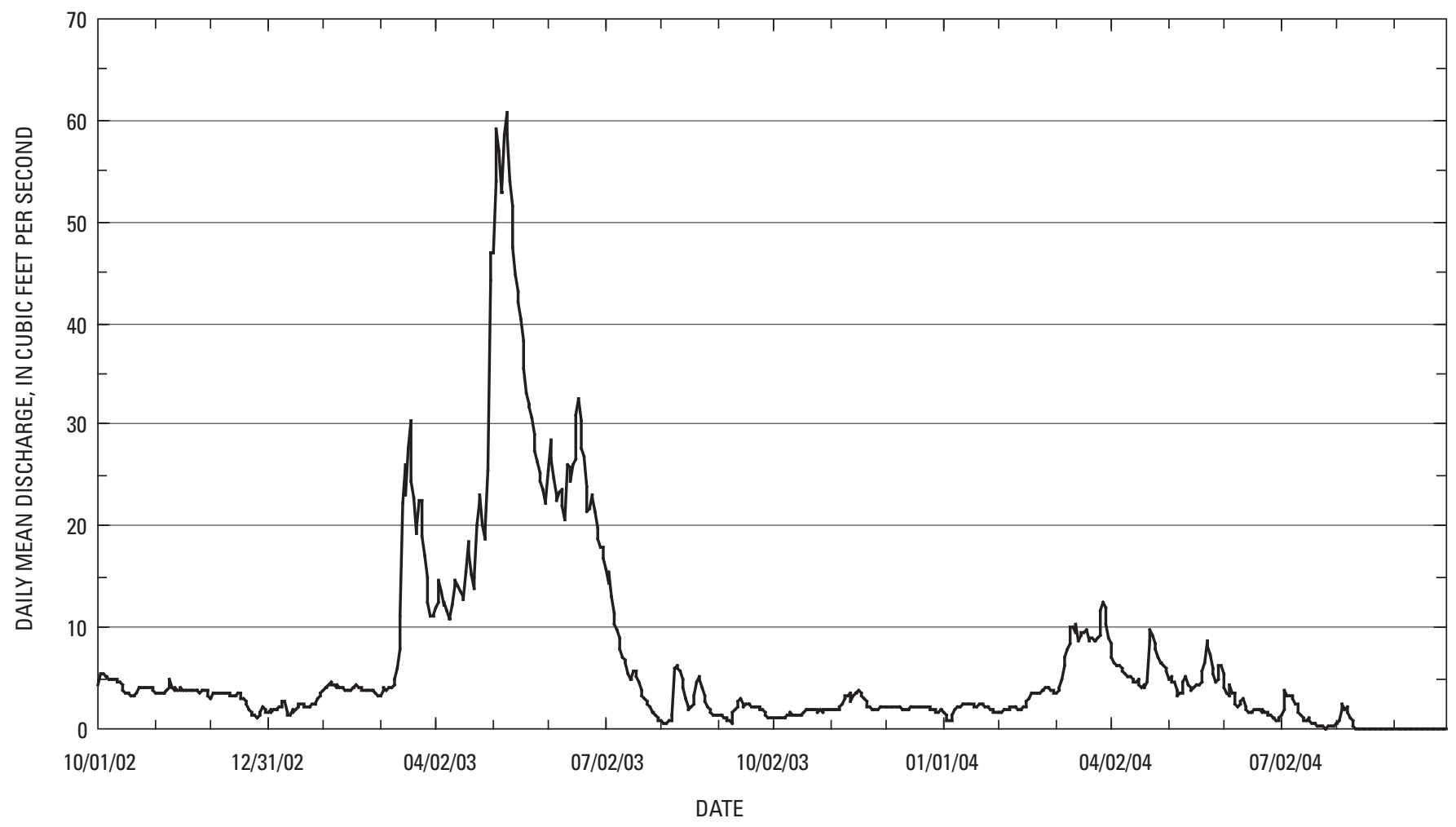

Figure 5. Daily mean streamflow for station 06407500 (Spring Creek near Keystone, South Dakota) located upstream from the streamflow loss zone. 


\section{Rapid Creek}

The Rapid Creek loss zone for the Madison Limestone includes about 2.2 river miles that cross the Madison Limestone outcrop (fig. 1). Streamflow losses or gains may occur within sections of the reach; however, a net loss always occurs over the length of the outcrop. The maximum net loss rate to the Madison aquifer (referred to as the loss threshold rate) was estimated to be about $10 \mathrm{ft}^{3} / \mathrm{s}$ (Hortness and Driscoll, 1998), which could include some loss to other hydrogeologic units such as the Deadwood and Minnelusa aquifers. Flow in Rapid Creek is regulated by Pactola Dam located about 7 miles (mi) west of the study area; therefore, streamflow usually exceeds the loss threshold rate.

The average altitude of the Rapid Creek loss zone is about $350 \mathrm{ft}$ lower than the Spring Creek loss zone because of geologic structural features (Miller, 2005). The thickness of the Madison Limestone in Rapid Creek Canyon is about $316 \mathrm{ft}$, compared to a thickness of $475 \mathrm{ft}$ in Spring Creek Canyon. The thickness of the upper two units described by Miller (2005) decreases from about 225 feet in Spring Creek Canyon to about $90 \mathrm{ft}$ in Rapid Creek Canyon. No easily identifiable swallow holes were noted in walking the streambed that crosses the Madison Limestone in the fall of 2004. Miller (2005) noted some depressions in the creek bottom that could be potential swallow holes. Discharge from Tittle Spring (TI-SP) (fig. 6), which is located slightly downstream from the center of the loss zone, generally ranges between 1 and $3 \mathrm{ft}^{3} / \mathrm{s}$ (Hortness and Driscoll, 1998). Analysis of ground-water and surface-water interactions along Rapid Creek (Hines, 1991) indicated that the loss-zone reach consistently loses streamflow; however, intermittent gains also occur within sections of the loss zone. Streamflow measurements at sites along the loss zone (Hines, 1991) indicate that the streamflow loss was distributed over the length of the loss zone without any reach accounting for a majority of the loss.

\section{Fluorescent Dye Tracing Methods}

Fluorescent dyes can be detected at very low concentrations in water samples by inserting glass ampoules containing the sample into a filter fluorometer. This instrument causes the dye in the sample to fluoresce when exposed to light of a particular band of wavelengths. The light emitted has a specific band of wavelengths for a particular dye. The fluorometer measures the relative magnitude of this emitted light, which is compared to known standard concentrations of the dye and then converted to a concentration value in units of mass per volume.

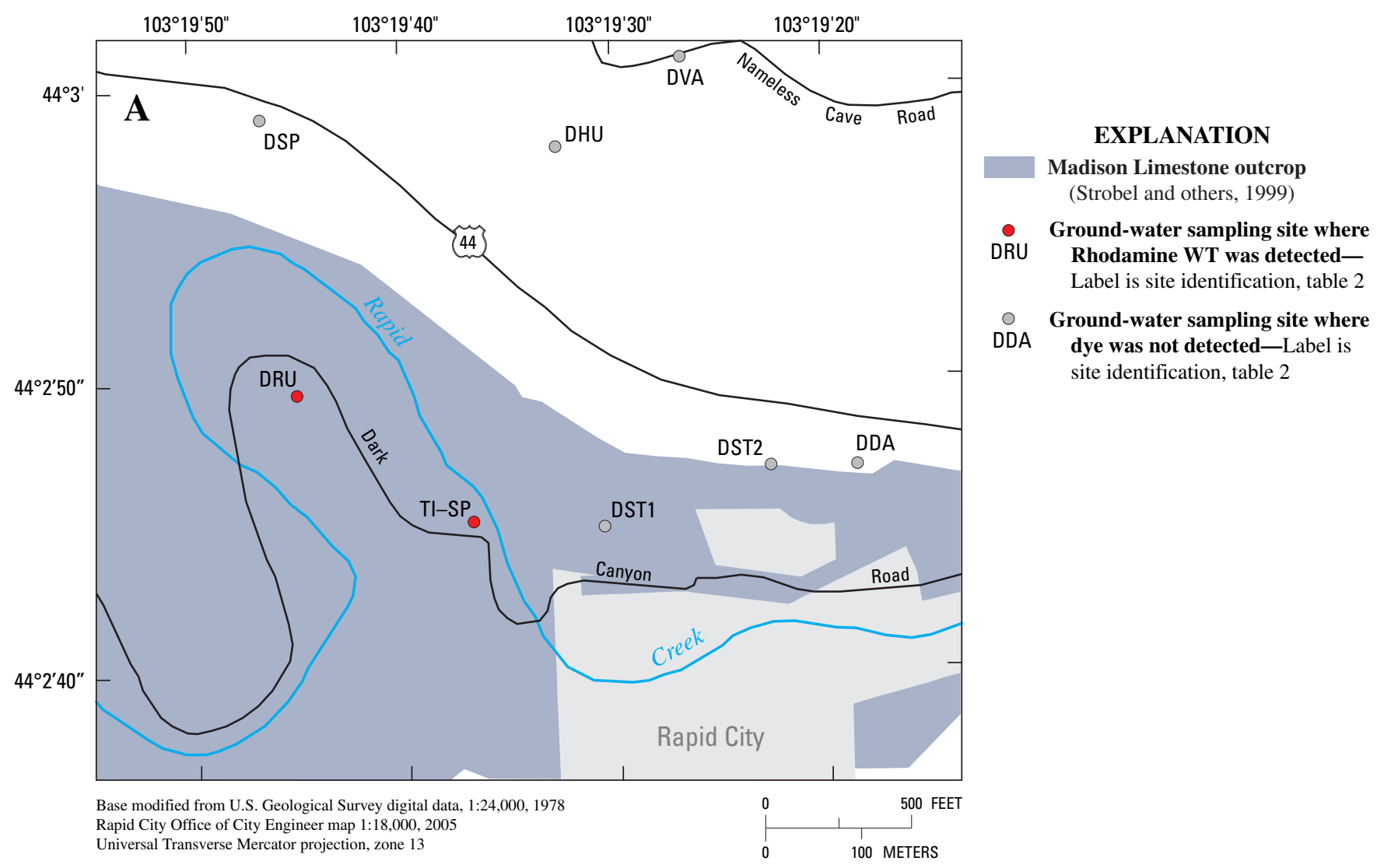

Figure 6. Location of sampling sites, Rapid Creek, South Dakota (see figure 1, insert A). 
Two types of tracer dyes were used in this study, sodium fluorescein and Rhodamine WT. The two dyes emit fluorescence at different ranges of wavelengths; thus, a sample containing a mixture of the two dyes can be analyzed for each dye separately with little interference. Sodium fluorescein is a water soluble form of fluorescein, which also is known as uranine. For simplicity, the term fluorescein was used to refer to sodium fluorescein in the following sections. The Chemical Abstract Service registry numbers are 518-47-8 for sodium fluorescein and 37299-86-8 for Rhodamine WT.

One way of tracing ground water in karst aquifers is to inject a known quantity of a dye in a stream or swallow hole and monitor for this dye at downgradient wells and springs. Determining the amount of dye to inject is based on the understanding of the hydrologic system. Often, reconnaissance testing with smaller dye concentrations is needed to design more robust tests. The frequency of sample collection and the location of sampling sites also are important considerations in designing the dye test. Reconnaissance testing was especially important in this study area because of the probability of direct connections to numerous public-water supplies.

\section{Dye Injections}

Four injections of fluorescein dye at sites S1-S4 were made during 2003-04 in the Spring Creek loss zone, and one injection of Rhodamine WT dye at site R1 was made during 2004 in the Rapid Creek loss zone (table 1; fig. 1). Injection at site S1 on April 29, 2003, was made in Spring Creek streamflow upstream from the loss zone with a continuous input of dye at a rate of about 90 micrograms per liter $(\mu \mathrm{g} / \mathrm{L})$ over a 12 -hour period (table 1$)$. Streamflow was sustained through almost the entire loss zone at this time. This continuous input approach was used to minimize the maximum dye concentration that potentially could reach a supply well. Also, some water supply storage reservoirs were filled prior to injection to minimize the potential concentrations that could occur in water supplies. The preliminary data from this injection were used to plan for subsequent injections in specific swallow holes. Injection at site S2 on May 22, 2003, was in the Deep Throat swallow hole, and injection at site S3 on May 29, 2003, was in the Lower Bend swallow hole. Injection at site S4 on March 28, 2004, was in the Joy's Loss swallow hole (table 1). The quantity of dye that could be injected was limited due to the direct connection to several supply wells that was observed during previous injections.

Table 1. Description of dye injections.

$[--$, none $]$

\begin{tabular}{|c|c|c|c|c|c|c|}
\hline $\begin{array}{c}\text { Dye } \\
\text { injection } \\
\text { site } \\
\text { (figure 1) }\end{array}$ & $\begin{array}{c}\text { Swallow hole } \\
\text { name from } \\
\text { Miller (2005) }\end{array}$ & Dye & $\begin{array}{l}\text { Dye quantity } \\
\text { (kilograms } \\
\text { of active } \\
\text { ingredient) }\end{array}$ & Injection period & $\begin{array}{l}\text { Streamflow } \\
\text { prior to } \\
\text { injection } \\
\text { (cubic feet per } \\
\text { second) }\end{array}$ & Description \\
\hline $\mathrm{S} 1$ & -- & Fluorescein & 2.20 & $\begin{array}{l}8 \text { p.m. on April 29, } \\
\text { 2003, to } 8 \text { a.m. on } \\
\text { April } 30,2003\end{array}$ & 20 & $\begin{array}{l}\text { Dye was injected continuously in } \\
\text { Spring Creek upstream from the } \\
\text { Madison Limestone outcrop at a rate } \\
\text { of about } 90 \text { micrograms per liter } \\
\text { over a } 12 \text {-hour period. }\end{array}$ \\
\hline $\mathrm{S} 2$ & Deep Throat & Fluorescein & 1.94 & $\begin{array}{l}6 \text { a.m. to } 6: 15 \text { a.m. } \\
\text { on May } 22,2003\end{array}$ & 32 & $\begin{array}{l}\text { Dye was injected into a small stream } \\
\text { entering the swallow hole on the } \\
\text { north side of Spring Creek over a } \\
\text { 15-minute period. }\end{array}$ \\
\hline $\mathrm{S} 3$ & Lower Bend & Fluorescein & 1.94 & $\begin{array}{l}8: 35 \text { a.m. to } 8: 50 \\
\text { a.m. on May 29, } \\
2003\end{array}$ & 24 & $\begin{array}{l}\text { Dye was injected into a small stream } \\
\text { entering the swallow hole on the } \\
\text { south side of Spring Creek over a } \\
\text { 15-minute period. }\end{array}$ \\
\hline $\mathrm{S} 4$ & Joy's Loss & Fluorescein & 2.05 & $\begin{array}{l}4 \text { p.m. to } 4: 35 \text { p.m. } \\
\text { on March } 28 \text {, } \\
2004\end{array}$ & 12 & $\begin{array}{l}\text { Dye was injected into the stream } \\
\text { entering the swallow hole on the } \\
\text { south side of Spring Creek over a } \\
\text { 35-minute period. }\end{array}$ \\
\hline R1 & -- & $\begin{array}{c}\text { Rhodamine } \\
\text { WT }\end{array}$ & 3.52 & $\begin{array}{l}\text { 10:00 a.m. on } \\
\text { October } 25,2004, \\
\text { to } 1: 50 \text { p.m. on } \\
\text { October } 26,2004\end{array}$ & 21 & $\begin{array}{l}\text { Dye was injected continuously in } \\
\text { Rapid Creek upstream from the } \\
\text { Madison Limestone outcrop over } \\
\text { a 27.8-hour period resulting in an } \\
\text { average stream concentration of } \\
\text { about } 60 \text { micrograms per liter. }\end{array}$ \\
\hline
\end{tabular}


An injection of Rhodamine WT dye (site R1) was made during 2004 in the Rapid Creek loss zone (table 1; fig. 1). Because of numerous supply wells near the loss zone and no identifiable swallow holes, the injection was metered into Rapid Creek upstream from the loss zone at a rate of about $60 \mu \mathrm{g} / \mathrm{L}$ over a 27.8-hour period (table 1). The streamflow during the injection was about $21 \mathrm{ft}^{3} / \mathrm{s}$ or about double the loss threshold rate of $10 \mathrm{ft}^{3} / \mathrm{s}$ (Hortness and Driscoll, 1998); therefore, about one-half the injected dye was assumed to have entered swallow holes in the Madison Limestone. A preliminary reconnaissance injection of fluorescein was made a week earlier to estimate stream transit times and design the injection.

\section{Sampling Sites}

Numerous supply wells completed in the Madison aquifer serve suburban communities and Rapid City within the study area. Stable isotope analyses by Anderson and others (1999), Naus and others (2001), and Long and Putnam (2002) indicate that Madison aquifer water south of Rapid City moves northward into the Rapid City area. Therefore, much of the water recharging the Madison aquifer from Spring Creek probably moves to the north or northeast toward the Jackson-Cleghorn Springs complex (figs. 1 and 7) converging with recharge from Rapid Creek and from infiltration of precipitation on the Madison Limestone outcrop between the two streams.

Sampled sites include 27 wells, 6 springs, and 3 stream sites (table 2; figs. 1, 6, and 7). Sampling frequency for most sites was daily or more frequent initially. Sampling frequency decreased to weekly intervals for many sites by the end of the sampling period. The sites that were sampled with each dye injection are listed in table 2 .

\section{Sample Collection}

Grab samples were collected from wells and springs by filling an opaque 250- or 500-milliliter high-density polyethylene bottle with non-chlorinated water as close to the source as possible. Cleghorn Springs (CL-SP) (fig. 7) was sampled from the Cleghorn Springs Fish Hatchery collection gallery through a manhole. Jackson Springs (JA-SP) (fig. 7) was sampled from the collection gallery sump in the Jackson Springs pumphouse. Stream samples were collected by combining six random grab samples collected across the width of the stream.

Samples for the three stream sites (RC-BB, RC-BC, and $\mathrm{RC}-\mathrm{AC}$ ) and some of the samples for spring site JA-SP were collected to evaluate the interaction of Madison aquifer springs and Rapid Creek near Jackson Springs (fig. 6). Jackson (JA-SP) and Cleghorn (CL-SP) Springs (fig. 6) are two large springs that together discharge about $21 \mathrm{ft}^{3} / \mathrm{s}$ from the Madison aquifer adjacent to Rapid Creek (Anderson and others, 1999). Rapid City operates an infiltration gallery in the Rapid Creek alluvium near Jackson Springs, which emerges in the alluvium and flows toward the creek. When the infiltration gallery is operating at full capacity, most of the spring discharge is captured by the gallery along with some induced infiltration from Rapid Creek. Cleghorn Springs emerges in the alluvium north and east of Jackson Springs and also flows toward Rapid Creek. SDGFP operates an infiltration gallery that collects most of Cleghorn Springs discharge for use in an adjacent fish hatchery. This water is circulated through the fish hatchery before it is returned to Rapid Creek downstream. A detailed description of the Jackson-Cleghorn Springs complex is provided in Anderson and others (1999). Measurements of dye concentrations in samples collected at 15-minute intervals at four sites, Rapid Creek above the complex (RC-BB) (fig. 1),

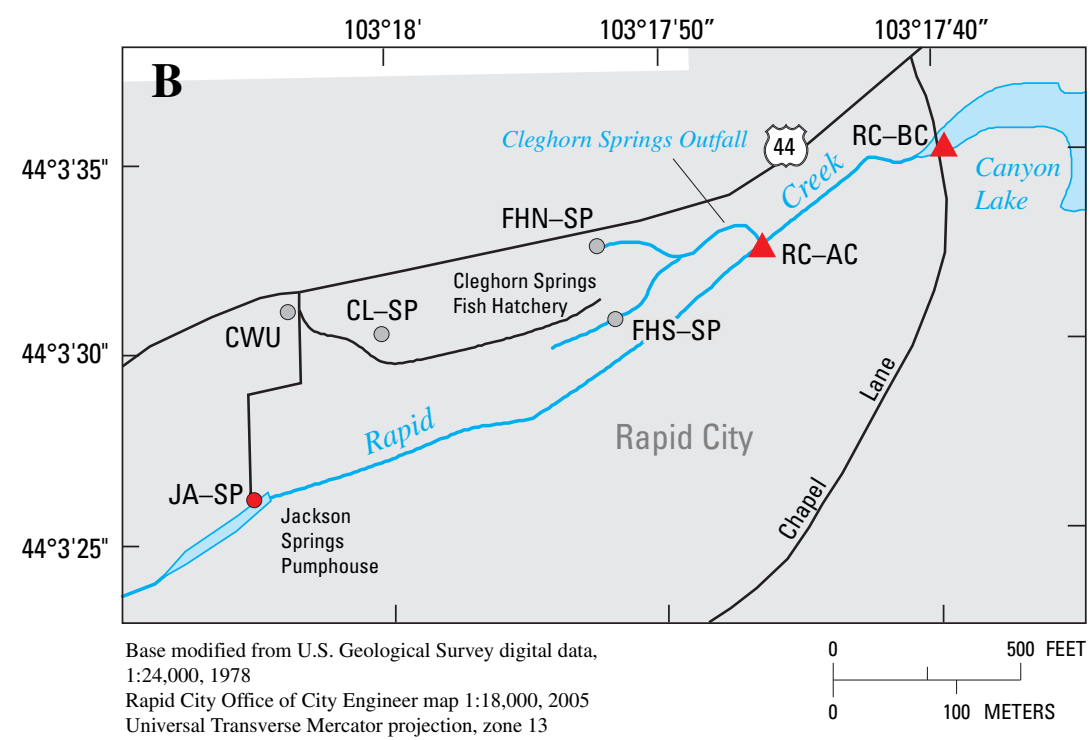

\section{EXPLANATION}

- Ground-water sampling site where JA-SP Rhodamine WT was detectedLabel is site identification, table 2

$\bigcirc$ Ground-water sampling site where dye CWU was not detected-Label is site identification, table 2

Stream sampling site for Rapid Creek$\mathrm{RC}-\mathrm{AC}$ Label is site indentification, table 2

Figure 7. Location of sampling sites, Rapid Creek, South Dakota (see figure 1, insert B). 
Table 2. Well, spring, and stream sites where samples were collected for dye analysis.

\begin{tabular}{|c|c|c|c|c|}
\hline $\begin{array}{l}\text { Sampling site } \\
\text { (figures 1, 6, } \\
\text { and 7) }\end{array}$ & $\begin{array}{c}\text { Station } \\
\text { identification } \\
\text { number }\end{array}$ & $\begin{array}{l}\text { U.S. Geological Survey } \\
\text { local number or station name }\end{array}$ & Site type & $\begin{array}{l}\text { Monitored tracer test } \\
\text { (injection site, table 1) }\end{array}$ \\
\hline $\mathrm{CO}$ & 435915103185401 & 1S 7E 5CBDD & Production well & S1, S2, S3, S4 \\
\hline NON & 440017103174301 & 1N 7E32ADBA & Production well & S1, S2, S3, S4 \\
\hline NAY & 440007103175301 & 1N 7E32DABB & Production well & $\mathrm{S} 1, \mathrm{~S} 2, \mathrm{~S} 3, \mathrm{~S} 4$ \\
\hline $\mathrm{HH}$ & 440004103174001 & 1N 7E32DABA & Production well & S1, S2, S3, S4 \\
\hline CRO & 440037103174401 & 1N 7E29DDC & Production well & $\mathrm{S} 1, \mathrm{~S} 2, \mathrm{~S} 3, \mathrm{~S} 4$ \\
\hline CSN4 & 440040103181401 & 1N 7E29CDDB & Production well & S1, S2, S3, S4 \\
\hline $\mathrm{SC}$ & 435930103191401 & 1S 7E 6 ADAB & Production well & $\mathrm{S} 1, \mathrm{~S} 2, \mathrm{~S} 3$ \\
\hline CLA & 440019103181801 & 1N 7E32BDBB & Production well & $\mathrm{S} 1, \mathrm{~S} 2, \mathrm{~S} 3$ \\
\hline $\mathrm{RR}$ & 440126103173201 & 1N 7E29AAAA & Irrigation well & $\mathrm{S} 1, \mathrm{~S} 4$ \\
\hline DEC & 440142103171601 & 1N 7E21CBDD & Domestic well & S1, S2, S3, S4 \\
\hline $\mathrm{CH}$ & 440223103173201 & 1N 7E17DDDA & Production well & $\mathrm{S} 1, \mathrm{~S} 2, \mathrm{~S} 3, \mathrm{~S} 4$ \\
\hline $\mathrm{RC} 11$ & 440220103164001 & 1N 7E16DCDC & Production well & S1, S2, S3, R1 \\
\hline DBU & 435903103181301 & 1S 7E 8ABAA & Domestic well & S2 \\
\hline CHLN2 & 440300103173501 & 1N 7E17AAAC2 & Production well & $\mathrm{S} 1, \mathrm{~S} 2, \mathrm{~S} 3, \mathrm{~S} 4, \mathrm{R} 1$ \\
\hline HR2 & 435851103143501 & 1S 7E11ACAB & Production well & $\mathrm{S} 1, \mathrm{~S} 2, \mathrm{~S} 3, \mathrm{~S} 4$ \\
\hline RC9 & 440342103160701 & 1N 7E10BCDB & Production well & S1, S2, S3, R1 \\
\hline CSN3 & 440059103175302 & 1N 7E29DBAA & Production well & S4 \\
\hline CL-SP & 440327103180503 & Cleghorn Springs & Spring & S1, S2, S3, R1 \\
\hline JA-SP & 440327103180501 & Jackson Springs & Spring & $\mathrm{S} 1, \mathrm{~S} 2, \mathrm{~S} 3, \mathrm{R} 1$ \\
\hline $\mathrm{RC}-\mathrm{BB}$ & 440321103181101 & Rapid Creek at Braeburn Addition & Stream & $\mathrm{R} 1$ \\
\hline $\mathrm{RC}-\mathrm{AC}$ & $\left({ }^{1}\right)$ & $\begin{array}{l}\text { Rapid Creek above Cleghorn Springs } \\
\text { outfall }\end{array}$ & Stream & $\mathrm{R} 1$ \\
\hline $\mathrm{RC}-\mathrm{BC}$ & 06412900 & Rapid Creek below Cleghorn Springs & Stream & $\mathrm{R} 1$ \\
\hline TI-SP & 440243103193701 & 1N 7E18CBAA (Tittle Spring) & Spring & $\mathrm{R} 1$ \\
\hline DRU & 440248103194501 & 1N 7E18BCDC & Domestic well & $\mathrm{R} 1$ \\
\hline FHS-SP & 06412700 & $\begin{array}{l}\text { Cleghorn Springs South Channel at } \\
\text { Fish Hatchery }\end{array}$ & Spring & $\mathrm{R} 1$ \\
\hline FHN-SP & 06412800 & $\begin{array}{l}\text { Cleghorn Springs North Channel at } \\
\text { Fish Hatchery }\end{array}$ & Spring & $\mathrm{R} 1$ \\
\hline CWU & 440327103180508 & $1 \mathrm{~N} 7 \mathrm{E} 8 \mathrm{DBCB}$ & Spring & $\mathrm{R} 1$ \\
\hline DST1 & 440245103192901 & $1 \mathrm{~N} 7 \mathrm{E} 18 \mathrm{CABA}$ & Domestic well & $\mathrm{R} 1$ \\
\hline DST2 & 440247103192101 & 1N 7E18BDDD1 & Domestic well & $\mathrm{R} 1$ \\
\hline DSP & 440228103194701 & 1N 7E18BCAB & Domestic well & $\mathrm{R} 1$ \\
\hline DHU & 440302103194601 & 1N 7E18BDBA & Domestic well & $\mathrm{R} 1$ \\
\hline DDA & 440247103191701 & 1N 7E18ACCC & Domestic well & $\mathrm{R} 1$ \\
\hline DHI & 440247103192401 & 1N 7E18AACB & Domestic well & $\mathrm{R} 1$ \\
\hline DVA & 440301103192501 & 1N 7E18BACC & Domestic well & $\mathrm{R} 1$ \\
\hline DSH & 440312103194201 & 1N 7E 7CCDD1 & Domestic well & $\mathrm{R} 1$ \\
\hline RC6 & 440526103173001 & 2N 7E32ADDD & Production well & $\mathrm{R} 1$ \\
\hline
\end{tabular}

${ }^{1}$ Station identification number not established. 
the Jackson Springs Gallery (JA-SP), Rapid Creek above the Cleghorn Springs outfall (RC-AC), and below the complex (RC-BC) (fig. 7) during dye injection at site R1, were made to provide some insight into the interactions between Rapid Creek, the discharge of Madison aquifer springs, and the alluvium along Rapid Creek.

\section{Sample Analysis}

A Turner Designs model T-700 Laboratory fluorometer was used for the analyses performed for this study. Jones (1984) and Wilson and others (1986) provide more detailed technical information regarding filter fluorometer operation.

\section{Fluorescein}

Fluorescein (sodium fluorescein/uranine) is a yellowgreen dye that can be detected at concentrations as low as $0.1 \mu \mathrm{g} / \mathrm{L}$ (Jones, 1984). Background water samples not containing dye can cause fluorometer readings at higher concentrations than these detection limits. Some constituents in natural waters, such as clay and organic substances, have fluorescent properties, and instrument noise also may be a factor. Boxplots of background and blank concentrations (fig. 8) for water samples at selected wells indicate that background concentrations generally were less than $0.3 \mu \mathrm{g} / \mathrm{L}$. Concentrations in blank samples generally were less than $0.1 \mu \mathrm{g} / \mathrm{L}$ but were as much as $0.2 \mu \mathrm{g} / \mathrm{L}$ (fig. 8). On the basis of this information, the first arrival of detectable dye concentrations was estimated as $0.35 \mu \mathrm{g} / \mathrm{L}$. Background concentrations at different sites can vary spatially and temporally. An isolated sample with this concentration may not indicate the presence of dye conclusively; however, an upward trend beginning at this concentration was assumed to indicate the presence of fluorescein dye.

Because fluorescein concentrations are sensitive to sunlight exposure, samples were collected in opaque bottles. To test the loss of fluorescence, samples stored for about 1 year were reanalyzed and compared with the original analysis (fig. 9). The loss in dye concentration over this period of time averaged about 20 percent. Dye samples were usually collected over a several week period before analysis, and some loss of dye in sample storage is possible.

\section{Rhodamine WT}

Rhodamine WT is bright red at high concentrations and can be detected at concentrations as low as $0.01 \mu \mathrm{g} / \mathrm{L}$ with a fluorometer (Jones, 1984). The same considerations regarding background levels and instrument noise as described for fluorescein apply to Rhodamine WT, except that Rhodamine WT is not as sensitive to sunlight. Boxplots of Rhodamine WT background concentrations (fig. 10) in water samples

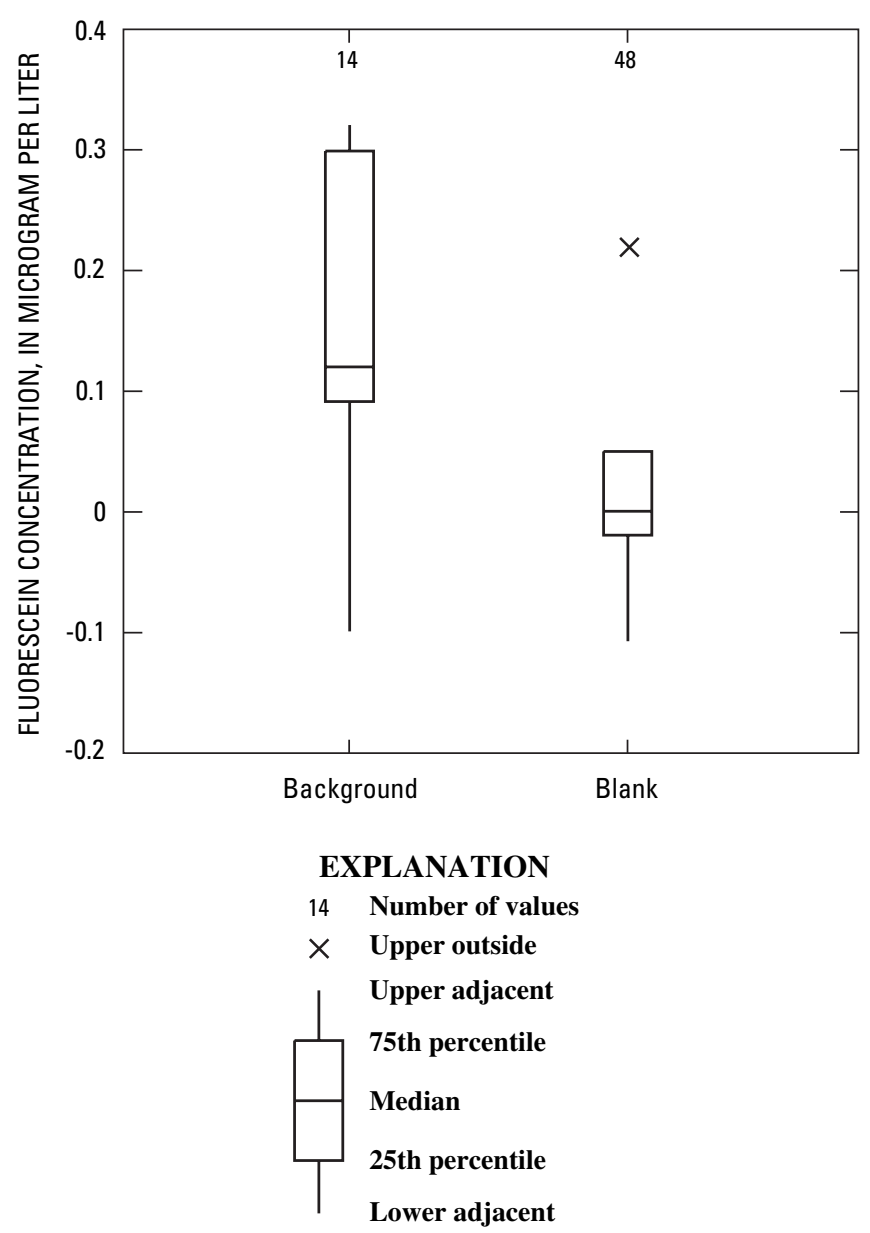

Figure 8. Boxplots of fluorescein concentrations in background and blank samples.

collected prior to dye injection at selected wells indicate that background concentrations generally were less than $0.03 \mu \mathrm{g} / \mathrm{L}$. Concentrations in blank samples generally were less than $0.03 \mu \mathrm{g} / \mathrm{L}$. Based on this information, the calculated first arrival of detectable dye concentrations was estimated as about $0.06 \mu \mathrm{g} / \mathrm{L}$. An isolated sample greater than this concentration may not indicate the presence of dye; however, an upward trend beginning at this concentration was assumed to indicate the arrival of Rhodamine WT dye.

In the analysis of samples with a filter fluorometer, there is a small area of overlap in the excitation wave length of fluorescein and Rhodamine WT around 550 nanometers (Jones, 1984). Samples with standard concentrations of fluorescein were analyzed using the Rhodamine filters in the filter fluorometer to quantify this potential overlap in wavelengths. The analysis of several different concentrations of fluorescein standards indicated that the presence of fluorescein dye did not interfere with the analysis of samples for Rhodamine WT. 


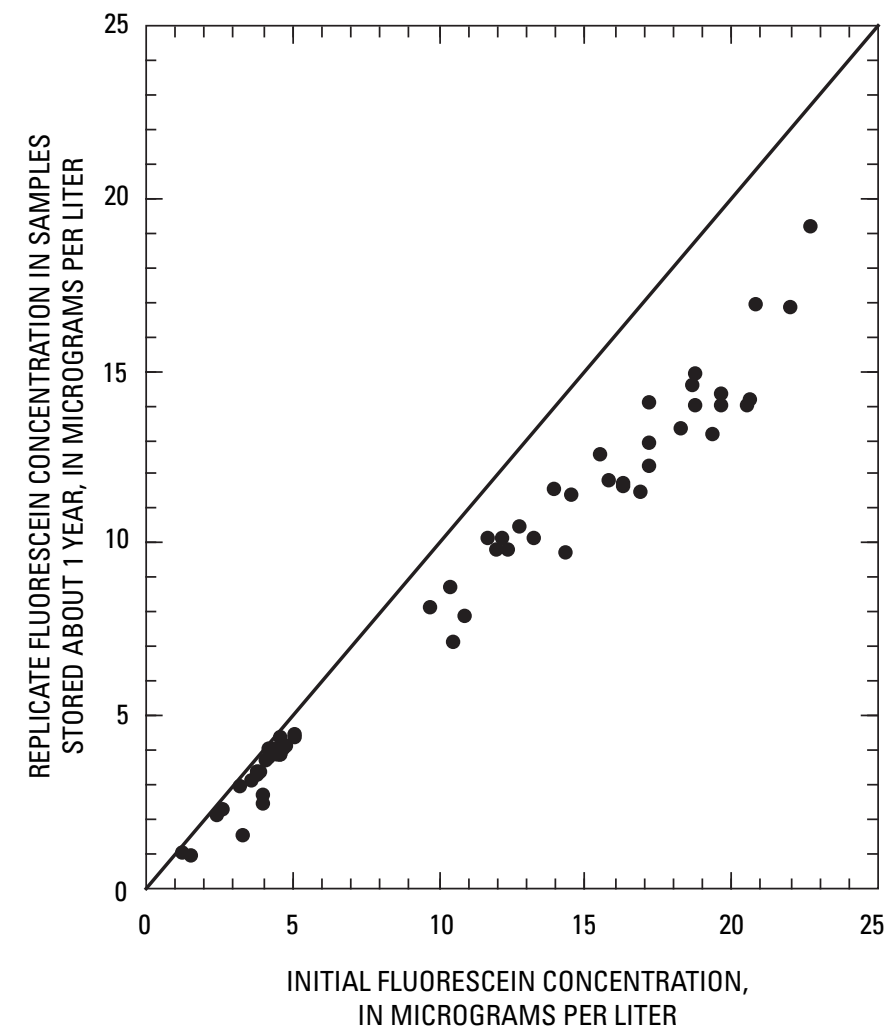

Figure 9. Comparison of initial fluorescein concentrations with concentrations in the same samples that were stored for about 1 year.

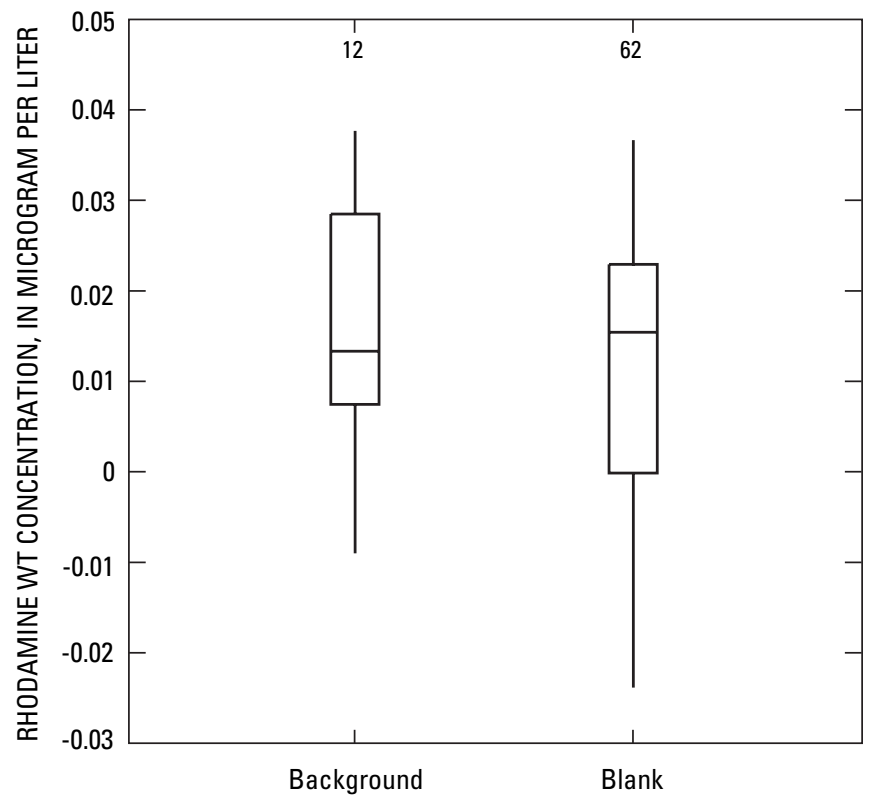

\section{EXPLANATION}

12 Number of values

Upper adjacent

75th percentile

Median

25th percentile

Lower adjacent

Figure 10. Boxplots of Rhodamine WT concentrations in background and blank samples. 


\section{Analysis of Ground-Water Flow Using Fluorescent Dyes}

Fluorescent dyes were used to analyze ground-water flow in the Madison aquifer from recharge areas in the Spring Creek and Rapid Creek loss zones. Dye tracing was used to determine dye concentrations in samples from downgradient sites and to estimate transit times of these conservative tracers to downgradient sites. Ground-water flow paths from the loss zones were determined based on the locations of sites where dye was detected. Ground-water velocities were estimated based on the first arrival of dye at downgradient sites.

\section{Concentrations and Transit Times of Fluorescent Dyes}

A summary of concentrations and transit times of fluorescent dyes is presented in this section of the report for the dye injections in the Spring Creek and Rapid Creek loss zones. Three injections of fluorescein dye were made in the Spring Creek loss zone in 2003 and one injection was made in 2004. One injection of Rhodamine WT dye was made in the Rapid Creek loss zone in 2004. Breakthrough curves, which are plots of dye concentrations with time, are presented for sites where a time series of detectable dye concentrations was measured.

\section{Spring Creek Loss Zone}

Fluorescein dye was injected at sites S1, S2, and S3 (fig. 1) in the Spring Creek loss zone during 2003. A total of 995 discrete samples (table 3 ) from wells and springs were collected and analyzed for fluorescein concentrations following the 2003 dye injections. In 2004, fluorescein dye was injected at site S4 (fig. 1) in the Spring Creek loss zone. A total of 158 discrete samples (table 4) from wells and springs were collected and analyzed for fluorescein concentrations following the 2004 dye injection. The fluorescein concentrations and transit times of the dye to downgradient wells and springs are summarized separately for 2003 and 2004 injections.

\section{Fluorescein Injections in 2003}

The first injection at site S1 upstream from the Spring Creek loss zone was designed for reconnaissance purposes to identify fast flow paths to nearby wells where potential exists for introducing high concentrations of dye to a water supply. Fluorescein dye was continuously injected into Spring Creek with a flow of about $20 \mathrm{ft}^{3} / \mathrm{s}$ over a 12 -hour period (table 1) that resulted in an average in-stream fluorescein concentration of about $90 \mu \mathrm{g} / \mathrm{L}$ that entered almost all potential swallow holes along Spring Creek. Fluorescein dye was detected in samples from five wells that were located as many as $2 \mathrm{mi}$ from the loss zone (table 3 ). The transit time of dye to these five wells was less than 10 days (table 3 ).

Fluorescein dye was detected at well CO (fig. 1) at 6:30 a.m. on April 30, 2003, in the first sample collected, which was about 0.89 days after the injection began at site $S 1$, and the concentration was $120 \mu \mathrm{g} / \mathrm{L}$ (table 3). At 5:15 p.m. that same day, another sample was collected that also had a fluorescein concentration of $120 \mu \mathrm{g} / \mathrm{L}$. The breakthrough curve for well CO (fig. 11) shows that fluorescein concentrations increased and then decreased rapidly within a few days. When fluorescein dye was injected on May 22 (about 22 days after the first injection) into Deep Throat swallow hole (site S2), located on the north side of the stream about 0.5 -mi upstream from well CO, analysis of samples collected during a 10-hour period following the injection did not indicate the presence of dye (fig. 11). When a sample was collected from well $\mathrm{CO}$ before the third injection at Lower Bend swallow hole (site S3) on May 29, a fluorescein concentration of $2.49 \mu \mathrm{g} / \mathrm{L}$ was measured, and the concentrations steadily decreased for samples collected several hours apart and for a sample collected the next day (fig. 11). This dye could be from injection at site S1 or S2, with S2 the most likely. Although a small set of discrete samples were collected from well CO, the results indicate differences in the hydraulic connection of well $\mathrm{CO}$ to individual swallow holes. Anastomosis of conduits near the stream channel or separate flow paths may explain the differences. 


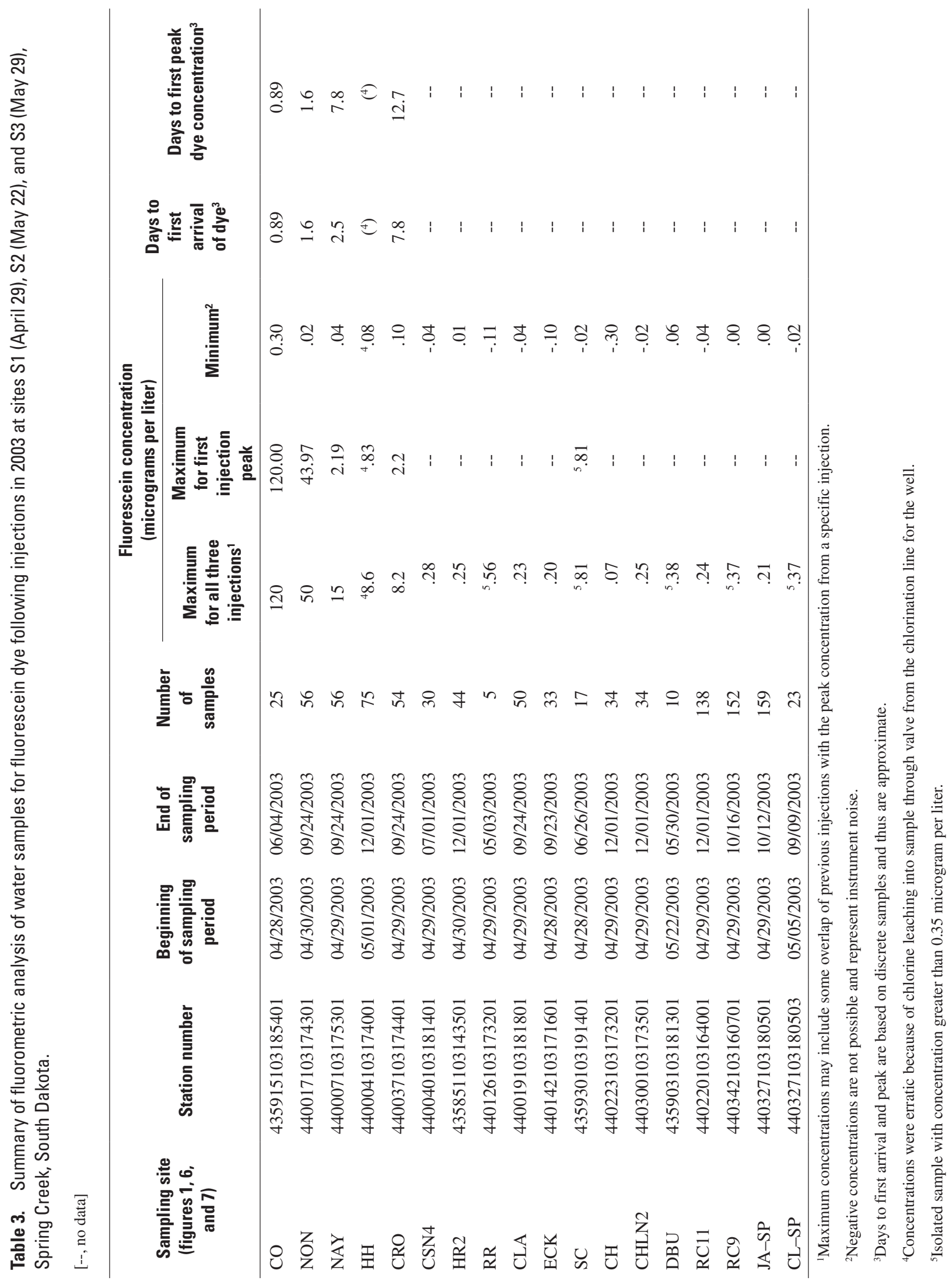




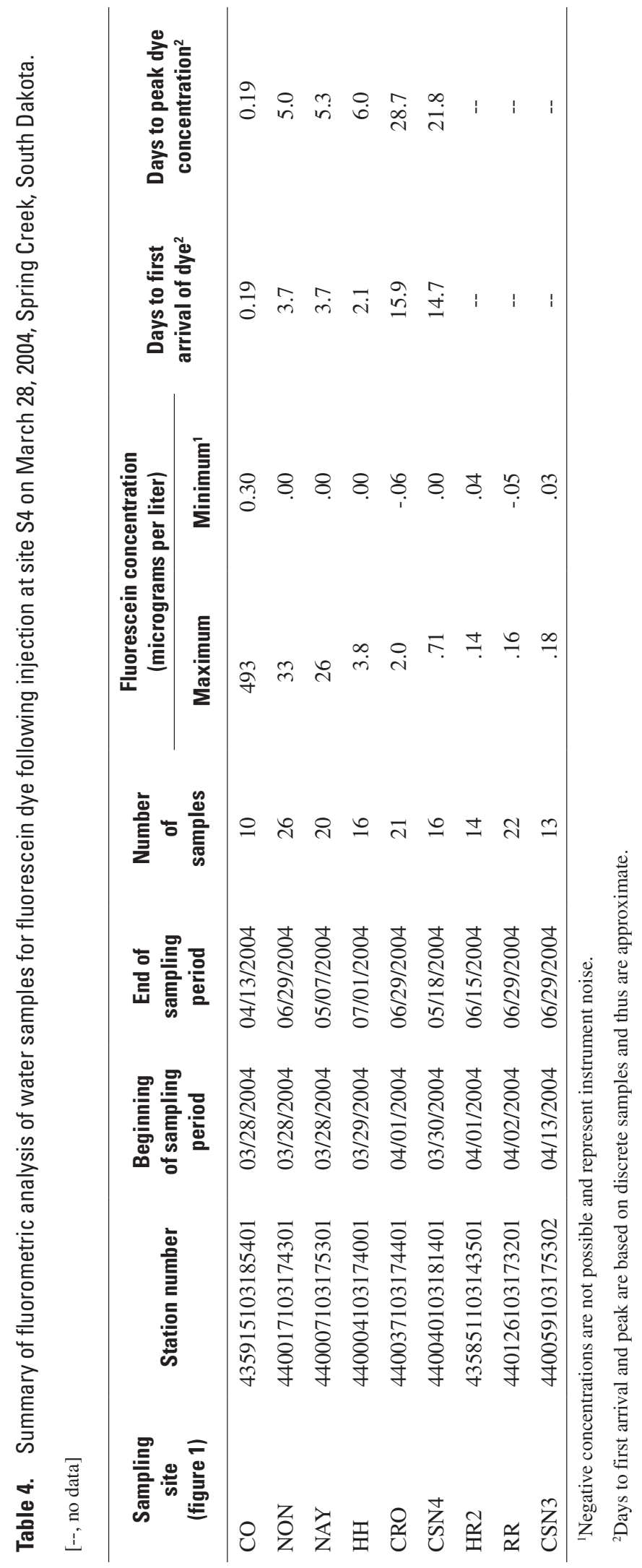




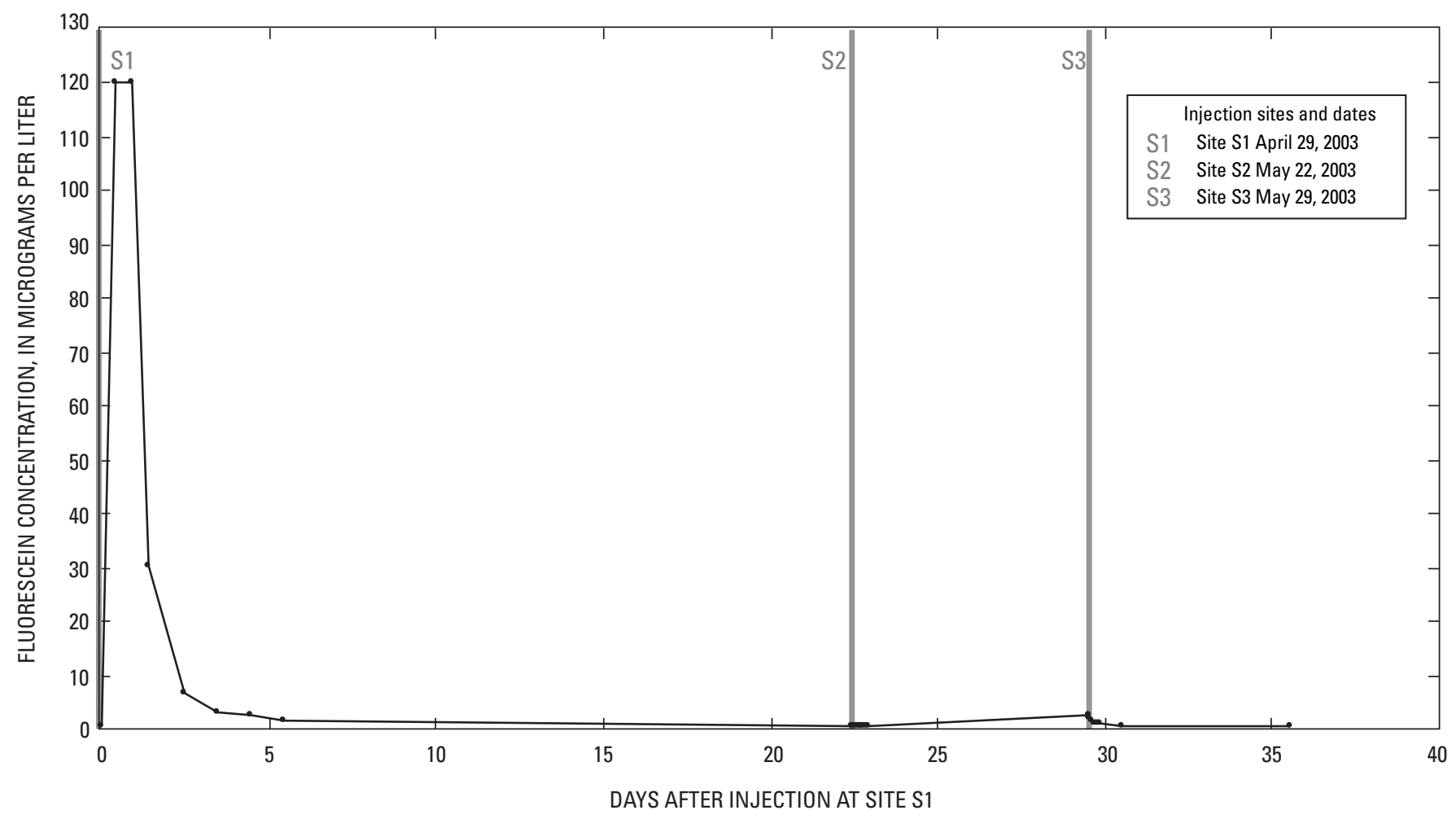

Figure 11. Fluorescein dye breakthrough curves for well CO following three dye injections in Spring Creek, South Dakota, in 2003.

The breakthrough curves for three wells (fig. 12) that were located 1 to 2 mi north and east of the Spring Creek loss zone (fig. 1) indicate a flow path to the northeast. Fluorescein dye also was detected at well $\mathrm{HH}$ in the same general area; however, some degradation of dye with small amounts of chlorine in the samples from water treatment at the well resulted in erratic values; therefore, the data were not shown on the graph of breakthrough curves. Valves were closed to isolate the chlorination line from the sample point; however, some chlorine occasionally leached through.

Fluorescein dye arrived at well NON within about 1.6 days after the beginning of dye injection at site S1 (table 3). The sample from well NON had a concentration of $43.97 \mu \mathrm{g} / \mathrm{L}$ (table 3 ; fig. 12), which was about one-half the average fluorescein concentration in the stream. The first arrival of dye could have been earlier than 1.6 days because the previous sample was collected about 18 hours earlier. A sample from well NON collected about 2 days after injection directly into the Deep Throat swallow hole (site S2) had a concentration of about $26 \mu \mathrm{g} / \mathrm{L}$ (fig. 12). A sample for well NON collected about 1 day after injection S3 directly into the Lower Bend swallow hole (site S3) had a concentration of about $50 \mu \mathrm{g} / \mathrm{L}$ (table 3; fig. 12). The peak concentrations are approximate because of the few discrete samples collected.

Well NAY is located about $1,000 \mathrm{ft}$ southwest of well NON (fig. 1) and is closer to the loss zone than well NON. Following injection at site $\mathrm{S} 1$, a sample collected from well NAY at about the same time as the sample in which dye was detected at NON did not indicate the presence of dye (fig. 12). A sample collected about 22 hours later had a dye concentration of $1.16 \mu \mathrm{g} / \mathrm{L}$. The concentrations increased slightly in samples from well NAY for several days to a maximum concentration of $2.19 \mu \mathrm{g} / \mathrm{L}$ (table 3 ) and then decreased to near background levels 21 days after the injection (fig. 12). About 2 days after injection at site S2, the fluorescein concentration in a sample from well NAY was $15 \mu \mathrm{g} / \mathrm{L}$ (table 3; fig. 12). Well NAY probably is near the preferential flow path that is connected to well NON, and the dye concentrations in samples from well NAY may have been influenced by the pumping schedule for well NAY.

The first arrival of dye at well CRO, which is located about 0.5 mi north of NON (fig. 1), occurred about 8 days after injection at site $\mathrm{S} 1$, with a maximum fluorescein concentration of about $2.2 \mu \mathrm{g} / \mathrm{L}$ occurring 5 days later (table 3 ; fig. 12). From this maximum, the concentration gradually decreased to $0.8 \mu \mathrm{g} / \mathrm{L}$ during the next 10 days. Injections at sites S2 and S3, which were made directly into swallow holes, resulted in fluorescein concentrations of about $7 \mu \mathrm{g} / \mathrm{L}$ for about a week beginning about 10 days after injection at site S2 (fig. 12). It is not known whether the maximum fluorescein concentration of $8.2 \mu \mathrm{g} / \mathrm{L}$ (table 3 ) at well $\mathrm{CRO}$ resulted from injection at site $\mathrm{S} 2$ or site $\mathrm{S} 3$, or from a combination of both injections. 


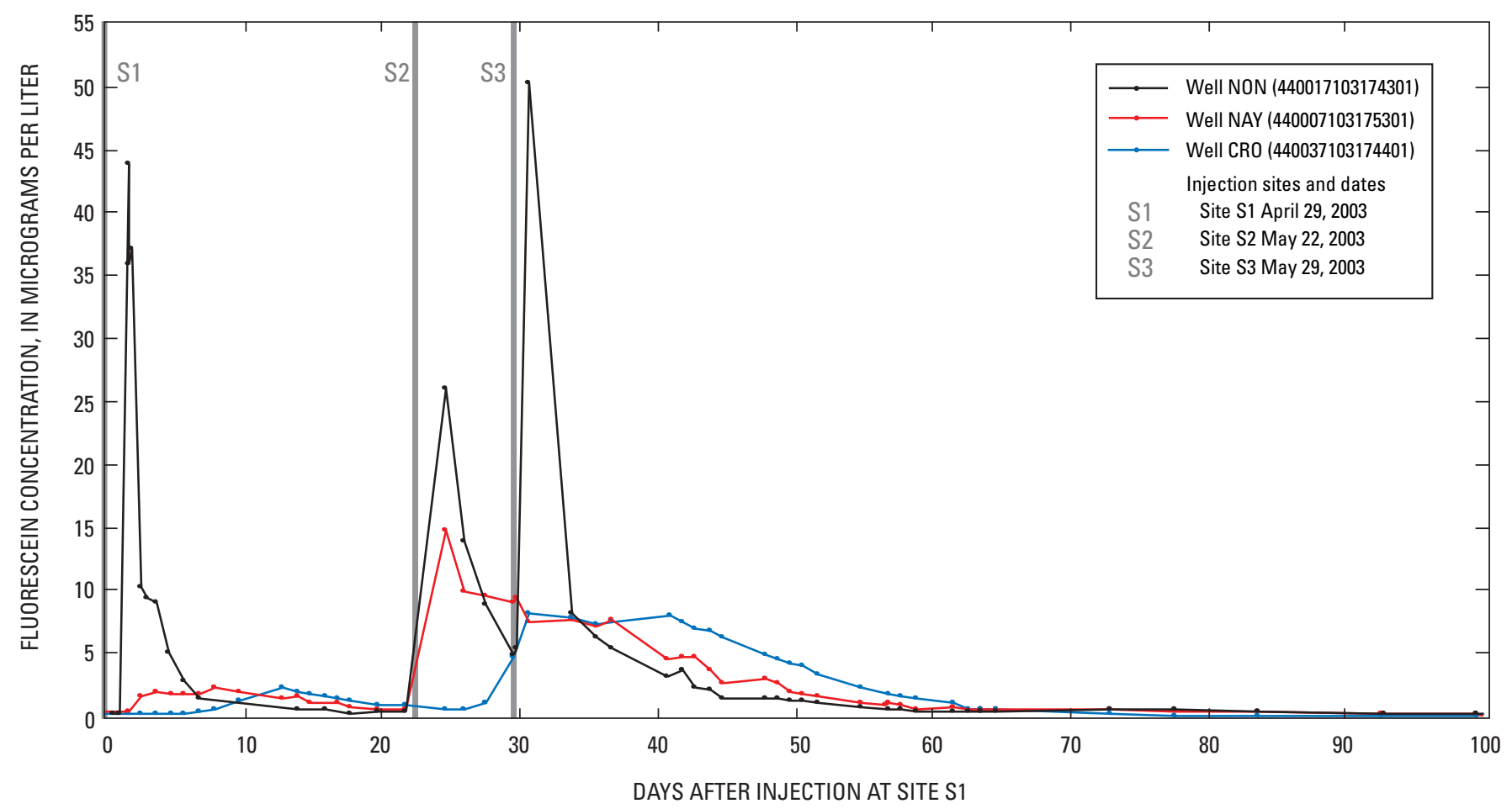

Figure 12. Fluorescein dye breakthrough curves for wells NON, NAY, and CRO following three dye injections in Spring Creek, South Dakota, in 2003.

\section{Fluorescein Injection in 2004}

The 2004 injection of fluorescein dye in Spring Creek was into Joy's Loss swallow hole (site S4) when streamflow was about $12 \mathrm{ft}^{3} / \mathrm{s}$ (table 1). This injection was made during the highest streamflow in 2004 (fig. 5), and Spring Creek streamflow began receding from the swallow hole soon after the injection. Streamflow recharge was considerably less in 2004 than in 2003. Dye was detected at well CSN4 (fig. 1) in addition to the five wells where dye was detected during the 2003 injections (table 4). In 2004, well CSN4 was being utilized as a production well; whereas, in 2003 the well was pumped only to collect the sample. Following the 2003 injections, the plumbing used to collect samples from well $\mathrm{HH}$ was modified to eliminate the possibility of chlorine leaching into the samples. Streamflow was low and transport of the dye was slower in 2004 compared to 2003, as shown by dye breakthrough curves for the six wells where dye was detected (figs. 13 and 14).

The maximum fluorescein concentration for well $\mathrm{CO}$ was $493 \mu \mathrm{g} / \mathrm{L}$ (table 4) in the first sample collected, which was about 0.19 day after the injection at site S4 (fig. 13). The fluorescein concentration decreased to about $40 \mu \mathrm{g} / \mathrm{L}$ the day after injection and to about $3 \mu \mathrm{g} / \mathrm{L} 15$ days after injection (fig. 13). Although the connection between the swallow hole at site S4 and well CO was direct, with dye arrival within hours, substantial dye concentrations remained many days later.

Fluorescein dye arrived at well NON about 3 days after injection at site S4 (table 4; fig. 14). The maximum fluorescein concentration of $33 \mu \mathrm{g} / \mathrm{L}$ occurred about 5 days after injection (table 4). The recession in the breakthrough curve in 2004 occurred more slowly than in 2003, with concentrations of about $10 \mu \mathrm{g} / \mathrm{L}$ remaining 25 days after injection. Fluorescein concentrations in samples from well NON returned to near background concentrations about 75 days later (fig. 14).

Fluorescein dye arrived at well NAY about 3 days after injection at site S4 (table 4; fig. 14). The maximum concentration of about $26 \mu \mathrm{g} / \mathrm{L}$ (fig. 14) occurred after about 5 days (table 4 ) and receded to near background levels about 40 days after injection. Dye arrived at well $\mathrm{HH}$ about 2 days after injection (table 4; fig. 14). The maximum fluorescein concentration of about $4 \mu \mathrm{g} / \mathrm{L}$ occurred about 6 days after the injection at site $\mathrm{S} 4$ (table 4; fig. 14).

Fluorescein dye arrived at well CRO about 16 days after injection (table 4). The maximum fluorescein concentration of about $2 \mu \mathrm{g} / \mathrm{L}$ occurred about 29 days after injection. First arrival of dye at well CSN4 also occurred about 15 days after injection at site $\mathrm{S} 4$, and the maximum fluorescein concentration of about $0.7 \mu \mathrm{g} / \mathrm{L}$ occurred about 22 days after injection (table 4; fig. 14). 


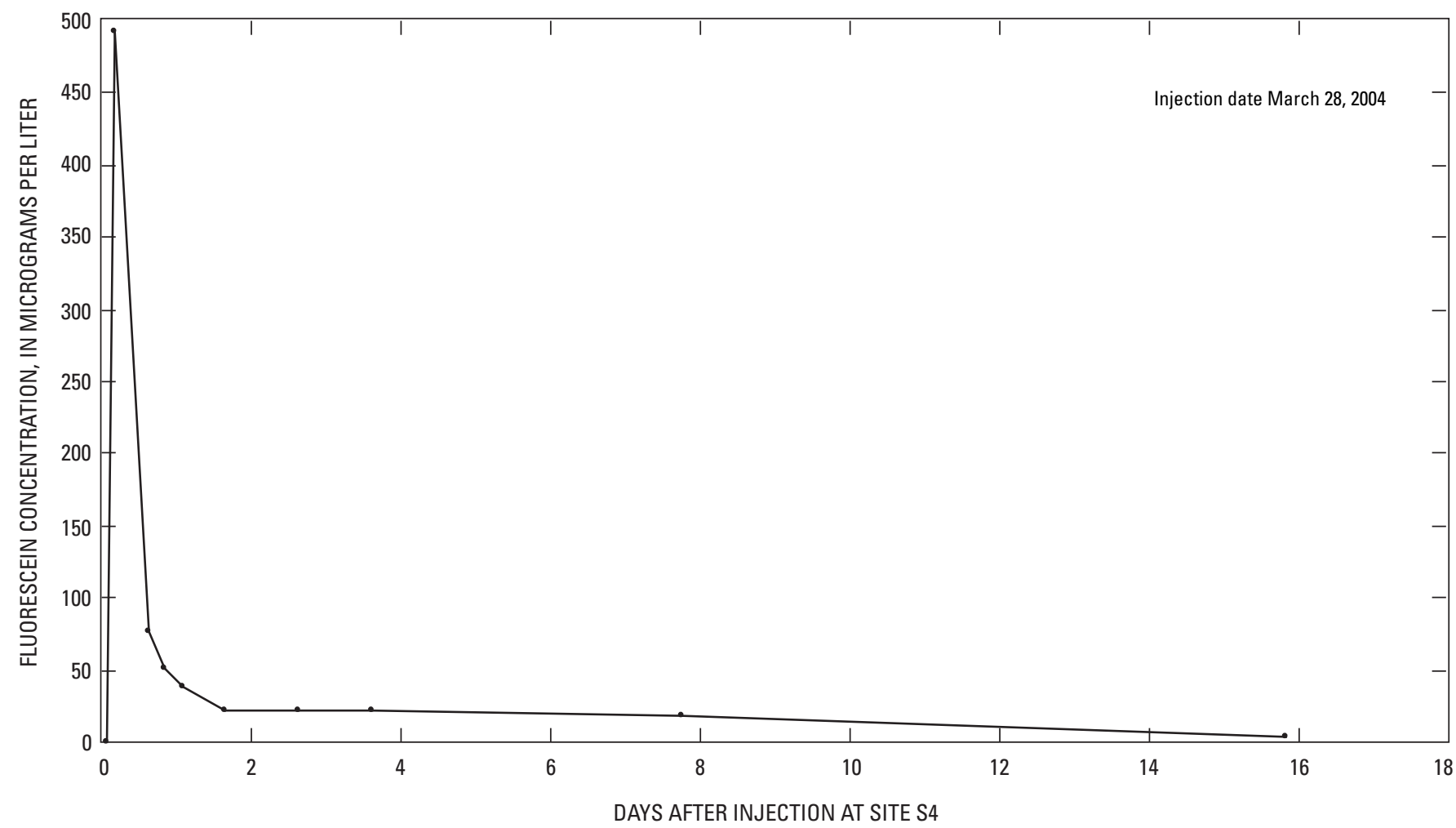

Figure 13. Fluorescein dye breakthrough curve for well CO following dye injection in Spring Creek, South Dakota, in 2004.

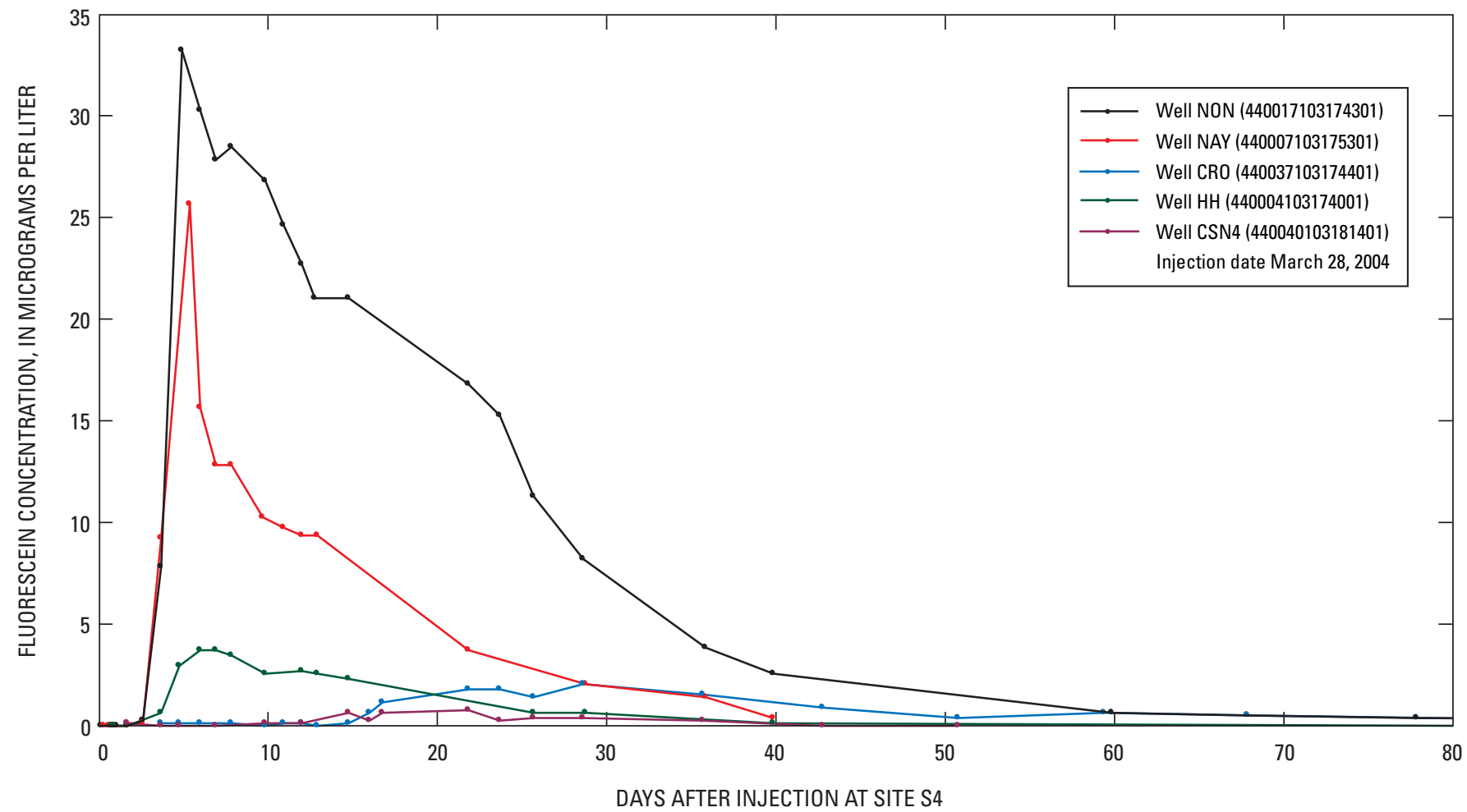

Figure 14. Fluorescein dye breakthrough curves for wells NON, NAY, CRO, HH, and CSN4 following dye injection in Spring Creek, South Dakota, in 2004. 


\section{Rapid Creek Loss Zone}

Rhodamine WT dye was injected at site R1 (fig. 1) in the Rapid Creek loss zone during 2004. A total of 511 discrete samples (table 5) from wells, springs, and stream sites were collected and analyzed for Rhodamine WT concentrations following injection. Additional samples were collected for 1 day at approximately 15 -minute intervals from Jackson Spring and three stream sites to provide information on the interaction between Rapid Creek and Jackson Springs. A summary of the time-series Rhodamine WT concentrations in samples from the stream sites and Jackson Springs also is presented.

For dye tracing in the Madison aquifer, the analyses of samples from wells completed in and springs discharging from the Madison aquifer (table 5) following the injection in Rapid Creek loss zone indicated the presence of dye in samples from well DRU and spring TI-SP (fig. 15). Well DRU and spring TI-SP are located near the center of the loss zone where there is a large meander in the creek (figs. 1 and 7). The first arrival of dye at well DRU was about 0.5 day after injection, and the maximum Rhodamine WT concentration of $6.2 \mu \mathrm{g} / \mathrm{L}$ was at about 1.5 days after injection at site R1 (table 5; fig. 15). The first arrival of dye at spring TI-SP was about 1.1 days after injection, and the maximum Rhodamine WT concentration of $0.91 \mu \mathrm{g} / \mathrm{L}$ occurred about 3 days after injection (table 5; fig. 15). Rhodamine WT concentrations were measured in samples from spring TI-SP 109 days after the dye injection (fig. 15). The estimates of first arrival and peak transit times are approximate because of the few discrete samples collected.

Rhodamine WT concentrations measured in samples from most of the other wells and springs were less than $0.06 \mu \mathrm{g} / \mathrm{L}$ (table 5) and did not indicate the presence of dye. The absence of detectable dye concentrations may be the result of the quantity of dye injected or the length of sampling period and does not necessarily prove that there is no connection to the streamflow loss zone on Rapid Creek. The maximum concentration of $0.45 \mu \mathrm{g} / \mathrm{L}$ (table 5) that was measured in a sample from site JA-SP collected about 38 hours (fig. 16) after the injection began was assumed to represent Rhodamine WT that was induced from Rapid Creek by the pumping of the Jackson Springs Gallery (fig. 6) while streamflow containing Rhodamine WT was flowing past site JA-SP. Rhodamine WT concentrations for samples from site JA-SP (fig. 16) that were slightly greater than $0.06 \mu \mathrm{g} / \mathrm{L}$ (detectable dye concentration) occurred after the Rhodamine WT concentrations returned to background concentrations of $0.035 \mu \mathrm{g} / \mathrm{L}$ or less for several days. The concentrations for 7 of the 15 samples collected 15 to 30 days after injection from site JA-SP had concentrations that ranged from 0.07 to $0.09 \mu \mathrm{g} / \mathrm{L}$ (fig. 16). Although these concentrations were slightly greater than the detectable dye concentration, no trend in concentrations was evident. The potential for movement of residual dye through the alluvium to the Jackson Springs Gallery also was a complicating factor that prevented drawing any conclusions from these low concentrations for samples collected 15 to 30 days after injection from site JA-SP.

Because of differences in the treatment requirements of ground water compared to ground water under the influence of surface water, a better understanding of the interaction between the Jackson Springs Gallery and Rapid Creek is an important issue for the city of Rapid City. The injection of Rhodamine WT in Rapid Creek provided an opportunity to compare Rhodamine WT concentrations in Rapid Creek with Rhodamine WT concentrations in the Jackson Springs Gallery with various pumping rates from the gallery.

For a 16-hour period on the day following the beginning of the 2004 Rapid Creek injection, samples from Jackson Springs Gallery (site JA-SP) and three stream sites (RC-BB, $\mathrm{RC}-\mathrm{AC}, \mathrm{RC}-\mathrm{BC}$ ) surrounding the Jackson-Cleghorn Springs complex (figs. 1 and 7) were collected (fig. 17). Site RC-BB is upstream from the Jackson-Cleghorn Springs complex, and site $\mathrm{RC}-\mathrm{AC}$ is located just upstream from the Cleghorn Springs Fish Hatchery outfall. Site RC-BC is located downstream from the Cleghorn Springs Fish Hatchery outfall. Pumping from the Jackson Springs Gallery was 1,800 gallons per minute ( $\mathrm{gal} / \mathrm{min}$ ) prior to the injection of dye until $10 \mathrm{a} . \mathrm{m}$. The pumping rate was increased to $3,100 \mathrm{gal} / \mathrm{min}$ from $10 \mathrm{a} . \mathrm{m}$. to $1 \mathrm{p} . \mathrm{m}$., then to $4,500 \mathrm{gal} / \mathrm{min}$ for the remainder of the day (fig. 17).

The average Rhodamine WT concentrations for the three stream sites were $32.12 \mu \mathrm{g} / \mathrm{L}$ for site RC-BB, $24.36 \mu \mathrm{g} / \mathrm{L}$ for site $\mathrm{RC}-\mathrm{AC}$, and $13.47 \mu \mathrm{g} / \mathrm{L}$ for site $\mathrm{RC}-\mathrm{BC}$ (fig. 17). The Rhodamine WT concentrations for Jackson Springs Gallery increased gradually as the pumping rate of the gallery was increased. The changes in Rhodamine WT concentrations were not abrupt in the Jackson Springs Gallery (site JA-SP) when the pumping rates were increased. More than 10 hours after the pumping rate was increased to $4,500 \mathrm{gal} / \mathrm{min}$, the dye concentration gradually increased from $0.16 \mu \mathrm{g} / \mathrm{L}$ to $0.45 \mu \mathrm{g} / \mathrm{L}$ in samples from site JA-SP (fig. 17). The average concentration in the stream over this period was about 25 to $30 \mu \mathrm{g} / \mathrm{L}$. At the end of the 10 -hour period at the high pumping rate, the Rhodamine WT concentration in samples from site JA-SP was less than 2 percent of the Rhodamine WT concentration in the stream. The Rhodamine WT concentrations were still increasing at the end of the sampling period. 


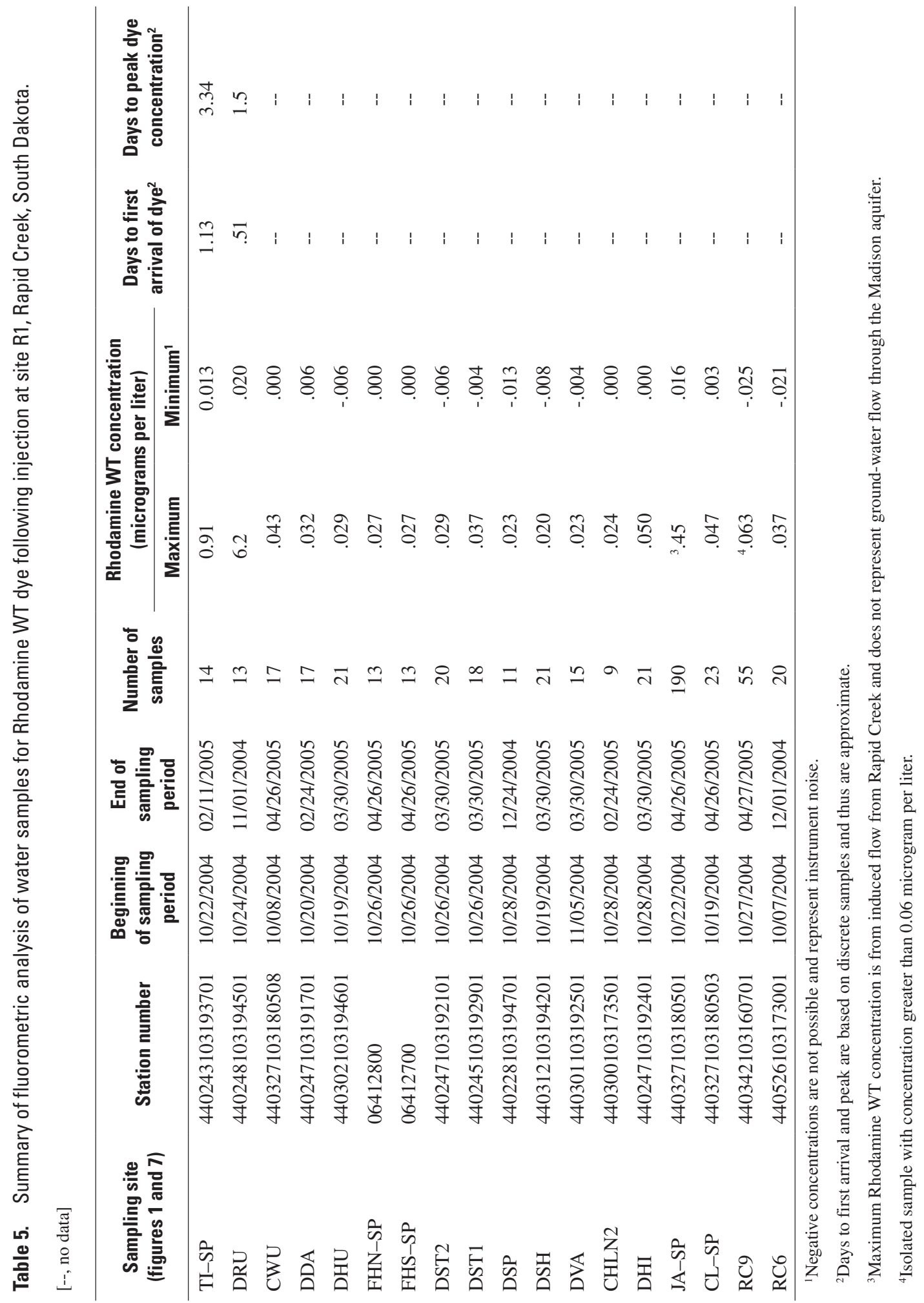




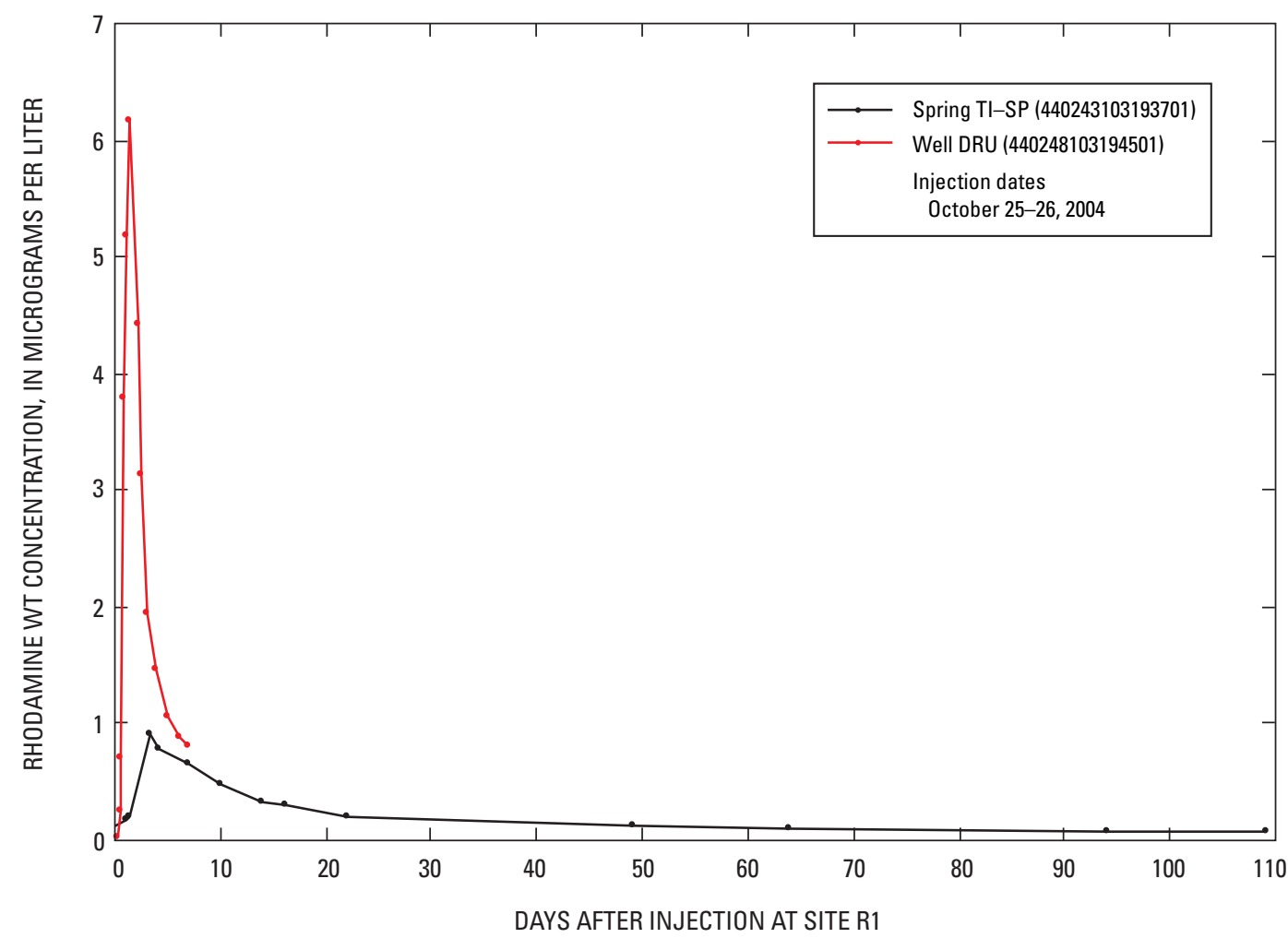

Figure 15. Rhodamine WT dye breakthrough curves for well DRU and spring TI-SP following dye injection in Rapid Creek, South Dakota, in 2004.

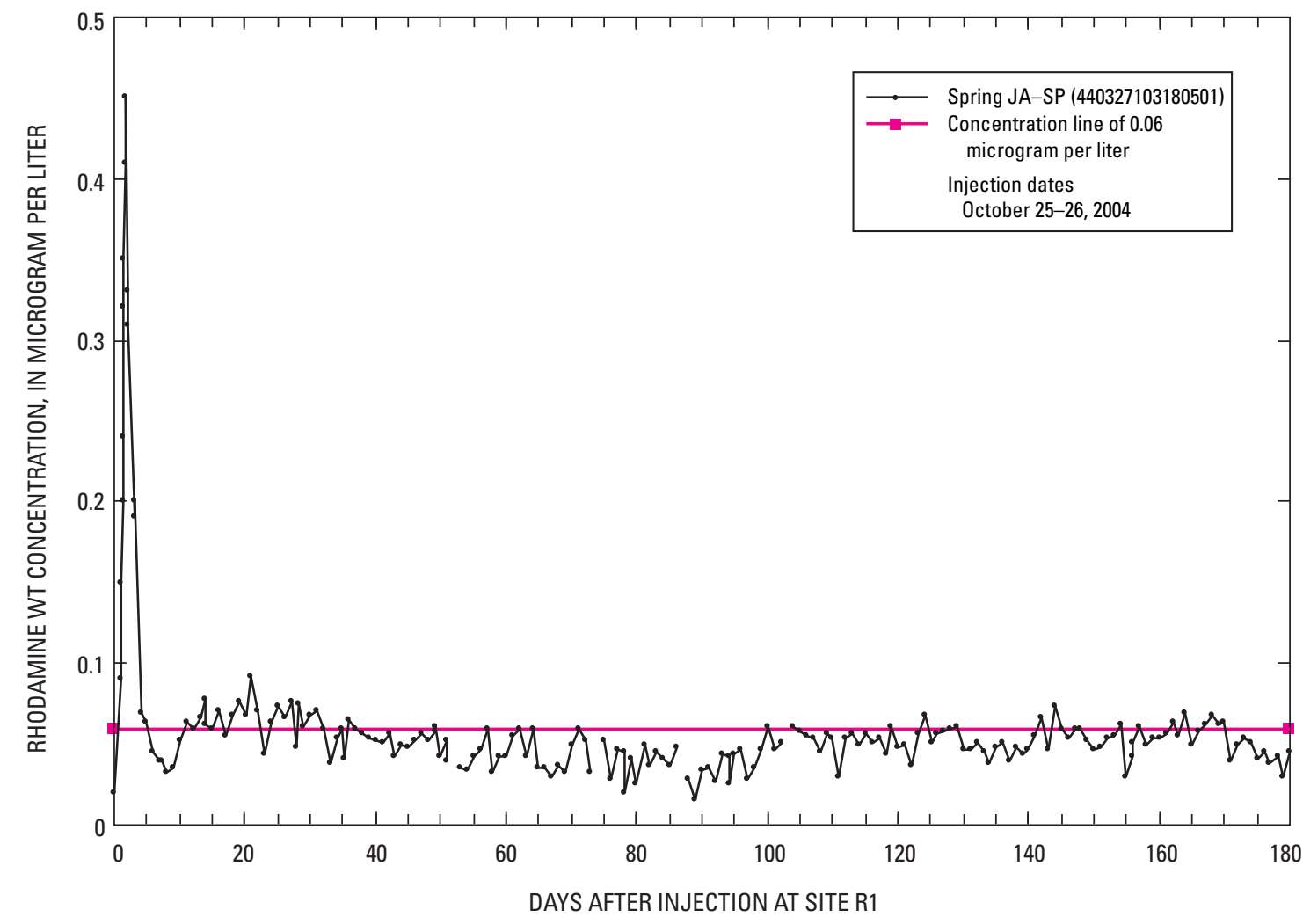

Figure 16. Rhodamine WT dye concentrations for Jackson Springs gallery samples following injection in Rapid Creek, South Dakota, in 2004. 


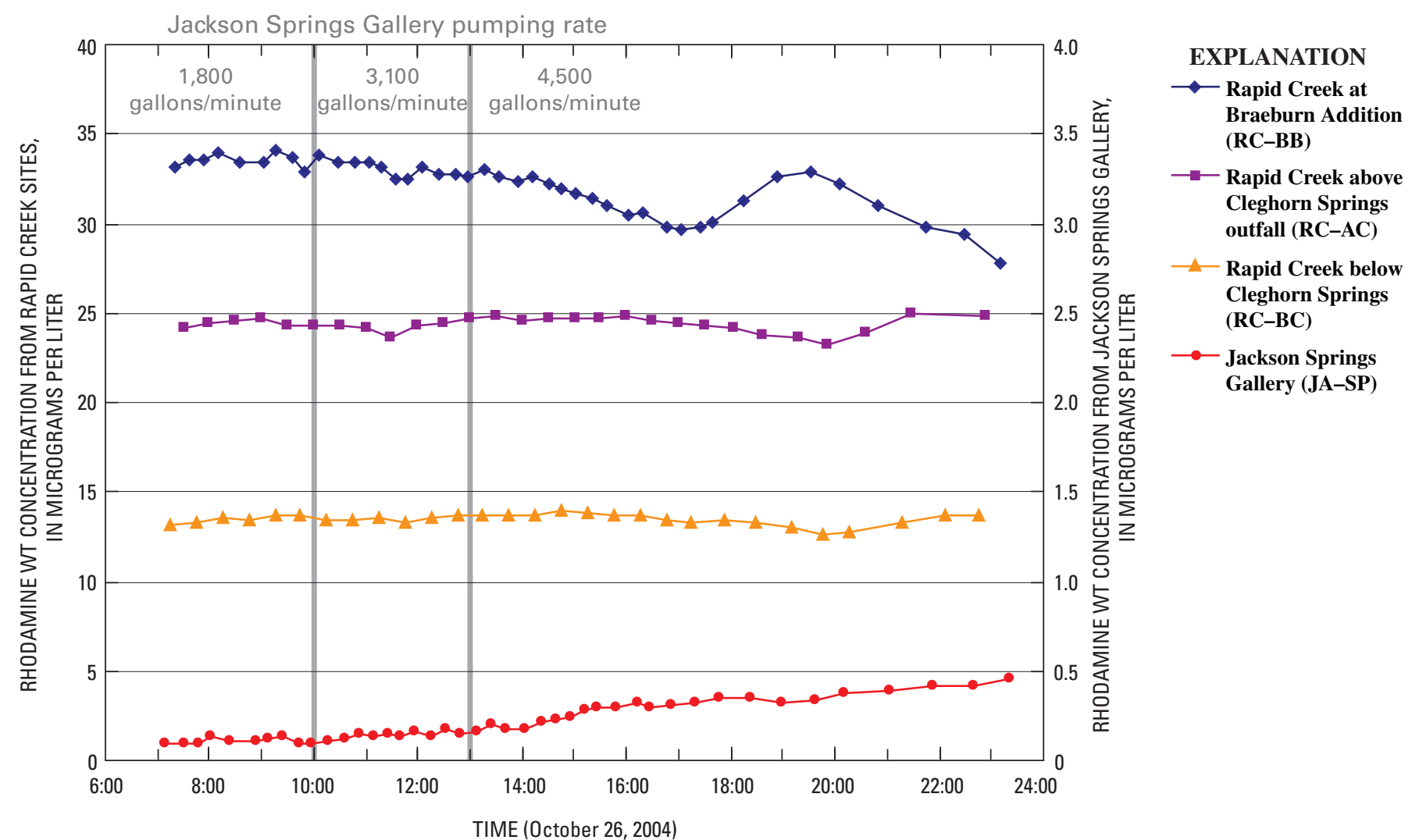

Figure 17. Time-series data of Rhodamine WT concentrations in samples from Rapid Creek sites and from Jackson Springs Gallery, Rapid Creek, South Dakota.

\section{Analysis of Ground-Water Flow Paths and Velocities}

The location of sites where fluorescein dye was detected following the Spring Creek dye injections (fig. 1) indicate a ground-water flow direction in the Madison aquifer that is east, then north from the streamflow loss zone. Dye breakthrough curves indicate conduit-dominated ground-water flow with this approximate orientation in the Spring Creek area. Well-defined flow paths were not identified in the Rapid Creek area east of the loss zone. Because of the few sampling sites and the complex ground-water flow system, potential flow paths could exist that were not identified in the study.

\section{Spring Creek Area}

The general direction of the flow path of dye from the Spring Creek loss zone is congruent with the flow path estimated by Long and Putnam (2002) (fig. 1). The transit times to downgradient wells in the Spring Creek area were consistent with an estimated transit time of 5 days for well $\mathrm{HH}$ (fig. 1) determined from the analysis of stable isotope timeseries data (Long and Putnam, 2004). Ground-water velocities calculated from the dye tracing ranged from about 770 to $6,500 \mathrm{ft} / \mathrm{d}$ (table 6 ) for wells that were about 1 to $2 \mathrm{mi}$ from the loss zone.

The dilution of fluorescein concentrations of about 50 percent for well NON compared to the in-stream concentration for injection at site S1 over a 12-hour period indicates that a conduit directs ground-water flow to the northeast. The detection of dye in samples from wells north of Spring Creek is consistent with previous descriptions of a flow path directing Spring Creek recharge toward the Jackson-Cleghorn Springs complex described in Long and Putnam (2002, 2004). Preferential ground-water flow paths probably have been developed between the swallow holes in Spring Creek and Jackson-Cleghorn Springs. Although fluorescein dye was not detected at Jackson or Cleghorn Springs, the groundwater flow path appears to be oriented in that direction. A substantially larger amount of tracer dye may be required to be detected at these springs, if this is the endpoint of the flow path.

Comparison of dye breakthrough curves for well NON for injections at sites S1 and S4 (figs. 1 and 18) shows that the length of time that a solute would remain in the capture zone of well NON is almost an order of magnitude greater when streamflow recharge is receding than when streamflow 
24 Analysis of Ground-Water Flow in the Madison Aquifer using Fluorescent Dyes near Rapid City, South Dakota, 2003-04

Table 6. Estimated ground-water velocities based on dye tracing for Spring Creek, South Dakota.

\begin{tabular}{lcccc}
\hline $\begin{array}{c}\text { Sampling site } \\
\text { (figure 1) }\end{array}$ & $\begin{array}{c}\text { Dye injection site } \\
\text { (figure 1) }\end{array}$ & $\begin{array}{c}\text { Days to first } \\
\text { arrival of dye }\end{array}$ & $\begin{array}{c}\text { Distance from } \\
\text { centroid of loss zone, } \\
\text { in feet }\end{array}$ & $\begin{array}{c}\text { Ground-water } \\
\text { velocity, } \\
\text { in feet per day }\end{array}$ \\
\hline NON & S1 & 1.6 & 10,400 & 6,500 \\
NAY & S1 & 2.5 & 9,400 & 3,760 \\
CRO & S1 & 7.8 & 12,200 & 1,564 \\
NON & S4 & 3.7 & 10,400 & 2,811 \\
NAY & S4 & 3.7 & 9,400 & 2,541 \\
HH & S4 & 2.1 & 9,400 & 4,476 \\
CRO & S4 & 15.9 & 12,200 & 767 \\
CSN4 & S4 & 14.7 & 15,200 & 1,034 \\
\hline
\end{tabular}

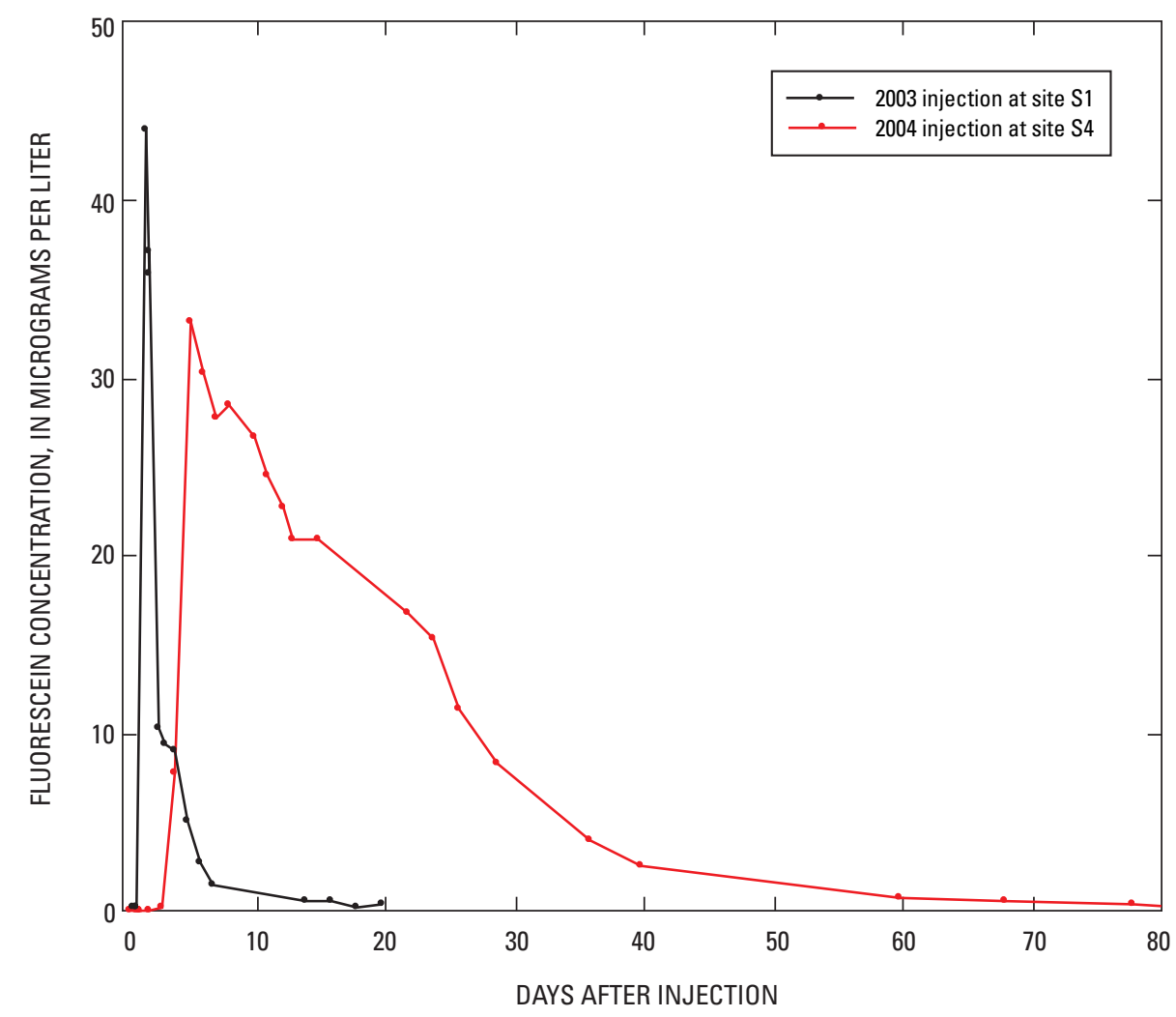

Figure 18. Comparison of fluorescein dye breakthrough curves for well NON for 2003 and 2004 injections in Spring Creek, South Dakota. 
recharge in Spring Creek is near the loss threshold rate. The dye concentrations in samples from well NON remained greater than $10 \mu \mathrm{g} / \mathrm{L}$ for about 25 days following injection at site S4 in 2004 compared to about 2 days following injection at site $\mathrm{S} 1$ in 2003. Differences in recharge rates could substantially influence the transport of a potential contaminant introduced into the Spring Creek loss zone.

The differences in dye concentrations in samples from wells NAY and CSN4 for the four fluorescein dye injections (figs. 12 and 14) indicate that pumping schedules and streamflow recharge characteristics could have an important influence on solute transport to production wells that have indirect connections to the conduit. The data for well CSN4 (figs. 12 and 14) indicate that when ground-water velocity in the conduit is high and pumping rates are low, solute concentrations could be small or not detectable. When the ground-water velocity in the conduit is slower and pumping rates are high, solute concentrations could be substantially larger.

\section{Rapid Creek Area}

A conduit flow path east of the loss zone was not evident from the dye injection in the Rapid Creek loss zone. Ground-water velocities in the Rapid Creek area could not be determined because the only two sites with detectable dye concentrations (fig. 7) were located within the loss zone. The number of wells available for sampling may have been inadequate to evaluate all potential flow paths. A potential explanation also could be dilution or dispersion of dye resulting from several factors. The thickness of the Madison Limestone in the Rapid Creek Canyon is about $316 \mathrm{ft}$ compared to a thickness of $475 \mathrm{ft}$ in Spring Creek Canyon (Miller, 2005). The thickness of the upper two units of the Madison Limestone described by Miller (2005) decreases from about $225 \mathrm{ft}$ in Spring Creek Canyon to about $90 \mathrm{ft}$ in Rapid Creek Canyon. The formation of conduits may be more likely in the upper two units than in the lower two units. The removal of the upper units by erosion may have resulted in a more diffuse network of solution openings in the Rapid Creek loss zone than in the Spring Creek loss zone. This is supported by Hines (1991), who indicated that the loss is more evenly distributed throughout the Rapid Creek loss zone.

Another potential factor is the relatively large and steady discharge from Jackson and Cleghorn Springs, which probably indicates the presence of many enlarged openings in the general area surrounding the springs. High transmissivity (40,000 feet squared per day) and large porosity in the Madison aquifer surrounding Jackson and Cleghorn Springs (Long and Putnam, 2002) may have caused greater dilution of dye than in other parts of the aquifer. Connections between the loss zone and the springs potentially could involve numerous smaller pathways with substantial dilution and mixing of the dye before discharge at Jackson or Cleghorn Springs.

\section{Summary}

The Madison aquifer, which is contained in the Mississippian-age Madison Limestone, is used extensively for water supplies for the city of Rapid City, S. Dak., and surrounding suburban communities. The 48-square-mile study area includes the west-central and southwest parts of Rapid City and the outcrops of the Madison Limestone extending from south of Spring Creek to north of Rapid Creek. The Madison Limestone is exposed on the western edge of the study area and dips to the east. An important component of recharge to the Madison Limestone is streamflow loss that occurs where streams cross the Madison Limestone outcrop (loss zone). The Madison Limestone, which is composed of limestone and dolostone, includes fractures and solution openings with karst features more prevalent in the upper parts than lower parts. The Spring Creek loss zone includes about 2.3 river miles, and the maximum net loss rate is 21 cubic feet per second $\left(\mathrm{ft}^{3} / \mathrm{s}\right)$. The Rapid Creek loss zone includes about 2.2 river miles, and the maximum net loss rate is $10 \mathrm{ft}^{3} / \mathrm{s}$. During 2003 and 2004, fluorescent dyes were injected in the Spring and Rapid Creek loss zones to estimate approximate locations of preferential flow paths in the Madison aquifer and to measure the response and transit times of a conservative tracer at wells and springs.

Four injections of about 2 kilograms of fluorescein dye at sites S1-S4 were made during 2003 and 2004 in the Spring Creek loss zone. Injection at site S1 on April 29, 2003, was made in streamflow just upstream from the loss zone over a 12-hour period when streamflow was about equal to the maximum loss rate. Injections at site S2 (May 22, 2003), site S3 (May 29, 2003), and site S4 (March 28, 2004) were in specific swallow holes located in the Spring Creek loss zone. Injection at site R1 (October 25-26, 2004) of 3.5 kilograms of Rhodamine WT dye was made in streamflow just upstream from the Rapid Creek loss zone over about a 28-hour period. Streamflow in Rapid Creek was about $21 \mathrm{ft}^{3} / \mathrm{s}$ compared to a maximum loss rate of about $10 \mathrm{ft}^{3} / \mathrm{s}$; therefore, approximately 50 percent of the injected dye was assumed to have moved into the Madison aquifer. A combination of 27 wells, 6 springs, and 3 stream sites were monitored with discrete samples following the injections.

For injections at sites S1-S3, when Spring Creek streamflow was greater than or equal to $20 \mathrm{ft}^{3} / \mathrm{s}$, fluorescein dye was detected in five wells that were located as many as about 2 miles from the loss zone, and time to first arrival ranged from less than 1 day to less than 10 days. The maximum concentration of 120 micrograms per liter $(\mu \mathrm{g} / \mathrm{L})$ at well $\mathrm{CO}$, located adjacent to the loss zone, was similar to the concentration in the stream during injection at site S1. Following injection at site S1, dye arrived within 1.6 days at well NON, and the maximum concentration was $44 \mu \mathrm{g} / \mathrm{L}$, which was about one-half the average stream concentration. For injection at site $\mathrm{S} 4$, when streamflow was about $12 \mathrm{ft}^{3} / \mathrm{s}$, 
time to first arrival of dye at the same five wells ranged from 0.2 to 16 days. Fluorescein dye also was detected at well CSN4 that was being used for water production in 2004; whereas, in 2003, this well was pumped only to collect samples. Following injection at site S4, the length of time that detectable dye remained in the capture zone of well NON, which is located approximately 2 miles from the loss zone, was almost an order of magnitude greater in 2004 than in 2003.

For injection at site R1, dye was detected at well DRU and spring TI-SP with time to first arrival of about 0.5 day and 1.1 days and maximum concentrations of 6.2 and $0.91 \mu \mathrm{g} / \mathrm{L}$, respectively. Well DRU and spring TI-SP are located near the center of the Rapid Creek loss zone where there is a large meander in the creek. Measurable concentrations were observed for spring TI-SP as many as 109 days after the dye injection. Samples were collected from the Jackson Springs Gallery, which is located in the alluvium downstream from the loss zone along Rapid Creek, when dye was present in the stream. For the 16-hour period when samples were collected from the gallery at approximately 15-minute intervals, pumping from the gallery was incrementally increased from 1,800 to 4,500 gallons per minute. After 10 hours at the high pumping rate, the Rhodamine WT concentrations in samples from the gallery increased from about 0.16 to $0.45 \mu \mathrm{g} / \mathrm{L}$.

The direction of a conduit flow path in the Spring Creek area was to the northeast with ground-water velocities that ranged from 770 to 6,500 feet per day. A conduit flow path east of the loss zone was not evident from the dye injection in the Rapid Creek loss zone.

\section{References Cited}

Anderson, M.T., Driscoll, D.G., and Williamson, J.E., 1999, Ground-water and surface-water interaction along Rapid Creek near Rapid City, South Dakota: U.S. Geological Survey Water-Resources Investigation Report 98-4214, $99 \mathrm{p}$.

Carter, J.M., Driscoll, D.G., Hamade, G.R., and Jarrell, G.J., 2001, Hydrologic budgets for the Madison and Minnelusa aquifers, Black Hills of South Dakota and Wyoming, water years 1987-96: U.S. Geological Survey Water-Resources Investigations Report 01-4119, 53 p.

Carter, J.M., and Redden, J.A., 1999a, Altitude of the top of the Minnelusa Formation in the Black Hills area, South Dakota: U.S. Geological Survey Hydrologic Investigations Atlas HA-744-C, 2 sheets, scale 1:100,000.

Carter, J.M., and Redden, J.A., 1999b, Altitude of the top of the Madison Limestone in the Black Hills area, South Dakota: U.S. Geological Survey Hydrologic Investigations Atlas HA-744-D, 2 sheets, scale 1:100,000.
Carter, J.M., and Redden, J.A., 1999c, Altitude of the top of the Deadwood Formation in the Black Hills area, South Dakota: U.S. Geological Survey Hydrologic Investigations Atlas HA-744-E, 2 sheets, scale 1:100,000.

Cattermole, J.M., 1969, Geologic map of the Rapid City west quadrangle, Pennington County, South Dakota: U.S. Geological Survey Geologic Quadrangle Map GQ-828, scale 1:24,000.

Driscoll, D.G., Hamade, G.R., and Kenner, S.J., 2000, Summary of precipitation data for the Black Hills area of South Dakota, water years 1931-98: U.S. Geological Survey Open-File Report 00-329, 163 p.

Ford, D.C., 1989, Features of the genesis of Jewel Cave and Wind Cave, Black Hills, South Dakota: National Speleological Society Bulletin, no. 51, p. 100-110.

Greene, E.A., 1993, Hydraulic properties of the Madison aquifer system in the western Rapid City area, South Dakota: U.S. Geological Survey Water-Resources Investigations Report 93-4008, 56 p.

Greene, E.A., 1999, Characterizing recharge to wells in carbonate aquifers using environmental and artificially recharged tracers, in Morganwalp, D.W., and Buxton, H.T., eds., Proceedings of the Technical Meeting, Charleston, S.C., March 8-12, 1999, Toxic Substances Hydrology Program: U.S. Geological Survey Water-Resources Investigations Report 99-4018-C, p. 803-808.

Greene, E.A., and Rahn, P.H., 1995, Localized anisotropic transmissivity in a karst aquifer: Ground Water, v. 33, no. 5, p. 806-816.

Gries, J.P., and Martin, J.E., 1985, Composite outcrop section of the Paleozoic and Mesozoic strata in the Black Hills and surrounding areas, in Rich, F.J., ed., Geology of the Black Hills, South Dakota and Wyoming (2d ed.): Field Trip Guidebook for the annual meeting of the Rocky Mountain Section of the Geological Society of America, Rapid City, S. Dak., April 1981, p. 261-292.

Hines, G.K., 1991, Ground-water and surface-water interaction in a reach of Rapid Creek near Rapid City, South Dakota: Rapid City, South Dakota School of Mines and Technology, unpublished M.S. thesis, 86 p.

Hortness, J.E., and Driscoll, D.G., 1998, Streamflow losses in the Black Hills of western South Dakota: U.S. Geological Survey Water-Resources Investigations Report 98-4116, $99 \mathrm{p}$.

Howard, A.D., 1964, A model for cavern development under artesian ground-water flow, with special reference to the Black Hills: National Speleological Society Bulletin, no. 26, p. 7-16. 
Jones, W.K., 1984, Dye tracer tests in karst areas: National Speleological Society Bulletin v. 46, no. 2, p. 3-9.

Long, A.J., and Putnam, L.D., 2002, Flow-system analysis of the Madison and Minnelusa aquifers in the Rapid City area, South Dakota—Conceptual model: U.S. Geological Survey Water-Resources Investigations Report 02-4185, 100 p., 3 pl.

Long, A.J., and Putnam, L.D., 2004, Linear model describing three components of flow in karst aquifers using ${ }^{18} \mathrm{O}$ data: Journal of Hydrology, v. 296, p. 254-270.

Miller, S.L, 2005, Influences of geologic structures and stratigraphy on ground-water flow paths in the karstic Madison aquifer in the Rapid City area: Rapid City, South Dakota School of Mines and Technology, unpublished Ph.D. dissertation, $191 \mathrm{p}$.

Naus, C.A., Driscoll, D.G., and Carter, J.M., 2001, Geochemistry of the Madison and Minnelusa aquifers in the Black Hills area, South Dakota: U.S. Geological Survey Water-Resources Investigations Report 01-4129, 118 p.

Rahn, P.H., 1971, The hydrologic significance of the November, 1986 dye test on Boxelder Creek, Black Hills, South Dakota: Proceedings, South Dakota Academy of Science, v. 50, p. 52-56.

Rahn P.H., and Gries, J.P., 1973, Large springs in the Black Hills, South Dakota and Wyoming: South Dakota Geological Survey Report of Investigations 107, 46 p.

Strobel M.L., Jarrell, G.J., Sawyer, J.F., Schleicher, J.R., and Fahrenbach, M.D., 1999, Distribution of hydrogeologic units in the Black Hills area, South Dakota: U.S. Geological Survey Hydrologic Investigations Atlas HA-743, 3 sheets, scale 1:100,000.

U.S. Geological Survey, 2004, Water resources data for South Dakota, water year 2003: U.S. Geological Survey WaterData Report SD-03-1 (published annually).

U.S. Geological Survey, 2005, Water resources data for South Dakota, water year 2004: U.S. Geological Survey WaterData Report SD-04-1 (published annually).

Wilson, J.F., Cobb, E.D., Kilpatrick, F.A., 1986, Fluorometric procedures for dye tracing: U.S. Geological Survey Techniques of Water-Resources Investigations, book 3, chap. A12, 34 p. 
This page intentionally left blank. 
Manuscript approved for publication, July 10, 2007.

Prepared by the Helena Publishing Service Center.

For more information concerning the research in this report, contact: U.S. Geological Survey

Director, South Dakota Water Science Center 1608 Mountain View Road

Rapid City, SD 57702

http://sd.water.usgs.gov/ 


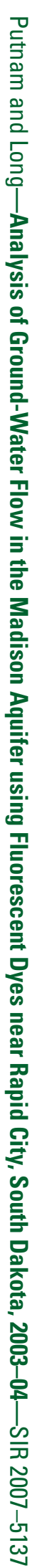

8 Printed on recycled paper 